\title{
Distribution patterns of the Malagasy freshwater crabs (Crustacea: Decapoda: Brachyura)
}

\author{
NEIL CUMBERLIDGE $\uparrow$, SADIE K. REED $\uparrow$ and \\ CHRISTOPHER B. BOYKO $\$$
}

$\dagger$ Department of Biology, Northern Michigan University, Marquette, MI 49855, USA; e-mail: ncumberl@nmu.edu $\$$ Division of Invertebrate Zoology, American Museum of Natural History,Central ParkWest@ 99 th St., New York, NY 10024, USA $\S$ Department of Biological Sciences, University of Rhode Island, Kingston, RI 02881, USA

(Accepted 12 November 2002)

An extensive faunal survey of freshwater habitats in Madagascar over a period of 9 years produced a large series of freshwater crabs from all six provinces on the island. The collections included three species of Hydrothelphusa (H. agilis, $H$. madagascariensis and $H$. goudoti), and specimens of three monotypic genera, Madagapotamon, Marojejy and Boreas. A detailed examination of a large series of specimens of $H$. madagascariensis of all ages from numerous locations throughout the island concluded that $H$. bombetokensis (Rathbun, 1904) should properly be treated as a junior objective synonym of $H$. madagascariensis A. MilneEdwards, 1872. Datasets combining the new records with literature records for all species of freshwater crabs in Madagascar were used to produce distribution maps. Overlaps in the distribution patterns of taxa indicate that there are centres of endemism (biodiversity hotspots) for freshwater crabs in the north-west lowland coastal region of Antsiranana Province in northern Madagascar.

Une surveillance faunistique extensive des habitats dulçaquicoles malgaches sur une période de neuf années, fournie une importante série de crabes d'eau douce provenant des six provinces de l'île. Les récoltes incluent trois espèces d'Hydrothelphusa (H. agilis, H. madagascariensis et $H$. goudoti), ainsi que des spécimens de trois genres monospécifiques, Madagapotamon, Marojejy et Boreas. L'examen détaillé d'une grande série de spécimens de tous ages de $M$. madagascariensis, provenant de régions géographiques distantes de l'île, nous amène à la conclusion que $H$. bombetokensis (Rathbun, 1904) doit probablement être considéré comme un junior synonyme objectif de $H$. madagascariensis A. Milne-Edwards, 1872. Des jeux de données prenant en compte les nouvelles récoltes et celles de la littérature de toutes les espèces de crabes d'eau douce de Madagascar, ont été utilisés pour établir les cartes de distribution des genres et des espèces. Le recouvrement des aires de distribution des taxons indiquent qu'il y a des centres d'endémisme ('biodiversity hotspots') pour les crabes d'eau douce des basses terres du Nord-Ouest de la province d'Antsiranana au Nord de Madagascar.

KeYwords: Crustacea, Brachyura, Potamoidea, Potamonautidae, freshwater crab, distribution, centre of endemism, biodiversity hotspot, Madagascar.

Journal of Natural History

ISSN 0022-2933 print/ISSN 1464-5262 online (C) 2004 Taylor \& Francis Ltd

http://www tandf.co.uk/journals

DOI: $10.1080 / 0022293031000068419$ 


\section{Introduction}

An extensive faunal survey of freshwater habitats in Madagascar over a period of 9 years produced a large series of freshwater crabs from all six provinces of the island. The majority of these specimens were collected by Jean-Marc Elouard and colleagues from the Institut de Recherche pour le Développement (IRD, ex-ORSTOM), and the Centre national de Recherche sur l'Environnement malgache (CNRE), as part of the 'Biodivertsité et Biotypologie des Eaux Continentales malgaches' programme. Over the course of the project some 836 localities in 44 major river basins were surveyed and freshwater crabs were found to be present at 52 localities (6.2\%) in 14 river basins in Madagascar. Elouard's material included some 91 specimens of Hydrothelphusa agilis A. Milne-Edwards, 1872 and 57 specimens of H. madagascariensis A. Milne-Edwards, 1872, covering a wide range of sizes. Also included here are specimens of freshwater crabs from more than 20 other localities collected by S. M. Goodman (FMNH) between 1992 and 1999. Goodman's specimens included H. agilis, H. madagascariensis, H. goudoti (H. Milne Edwards, 1853), Madagapotamon humberti Bott, 1965, Marojejy longimerus Cumberlidge, Boyko and Harvey, 2002, and Boreas uglowi Cumberlidge and Sternberg, 2002.

We follow here the classification proposed by Cumberlidge and Sternberg (2002) that recognized six genera of freshwater crabs in Madagascar, all endemic to the island. Identification of specimens was made using keys to the genera and species of Malagasy freshwater crabs (Cumberlidge and Sternberg, 2002).

Datasets combining the new records with literature records for all species of Malagasy freshwater crabs were used to produce comprehensive distribution maps based on all collection localities known to the authors. The results are discussed in terms of biomes, drainage basins and ecoregions in Madagascar (Sparks and Stiassny, in press; Thieme et al., in press). Overlaps in the distribution patterns of taxa with limited distributions indicate three centres of endemism (biodiversity hotspots) for freshwater crabs in the north-west coastal lowlands of Antsiranana Province in northern Madagascar.

The majority of the new material in the present study belongs to Hydrothelphusa A. Milne-Edwards, 1872, and this genus undoubtedly includes the largest and most widespread species of freshwater crabs in Madagascar. Species of Hydrothelphusa are found in rivers, streams and lakes, in both highland and lowland regions, and in forested and non-forested parts of the island. A detailed examination of a large series of specimens of $H$. madagascariensis of all ages from geographically distant parts of the island led to the conclusion that H. bombetokensis (Rathbun, 1904) should properly be treated as a junior objective synonym of $H$. madagascariensis A. Milne-Edwards, 1872. The number of species of freshwater crabs from Madagascar is therefore reduced from 12 species (Cumberlidge and Sternberg, 2002) to 11 species.

The other species included in the present study are much less abundant, and belong to monotypic genera (Madagapotamon Bott, 1965; Marojejy Cumberlidge, Boyko and Harvey, 2002; and Boreas Cumberlidge and Sternberg, 2002) with more restricted distributions. For completeness, we have also included distribution data for Malagasya Cumberlidge and Sternberg, 2002 and Skelosophusa Ng and Takeda, 1994 from the literature ( $\mathrm{Ng}$ and Takeda, 1994; Cumberlidge et al., 2002; Cumberlidge and Sternberg, 2002, in press).

\section{Material}

Jean-Marc Elouard and his colleagues (see Acknowledgements for details) surveyed a high number of localities (836) year-round, in 44 river basins in each of the 
five freshwater ecoregions recognized by Sparks and Stiassny (in press) and Thieme et al. (in press) (figure 1). We have added a number of other localities following direct examination of freshwater crabs from Madagascar in the collections of a number of museums (Cumberlidge, 1997 [NHMW], 1998 [ZSM]; Cumberlidge and Boyko, 2001 [FMNH]; Cumberlidge and Sternberg, 2002 [MNHN]). Despite these efforts, the levels of island-wide exploration are still uneven, which may be due to difficulties associated with the logistical considerations of surveying the more remote parts of the island.

Elouard and his colleagues concentrated their efforts in Antananarivo Province, along major roads linking Antananarivo to Toamasina and Fianarantsoa, and in the regions around Tolagnaro and Montagne d'Ambre (figure 1). The highest number of collection localities were in the central and south-eastern highlands and lowlands, on the slopes of Montagne d'Ambre in the far north, in the region around Tolagnaro in the far south, and in the western and north-western basins in the basin of the Betsiboka River (especially in the headwaters in Antananarivo Province). The lowest levels of collection were in the central west and extreme south-west of the island. The principal areas that remain unsurveyed for freshwater crabs are: (1) the northern highland and lowland regions north of Toamasina, including the Tsaratanana massif and the Masoala Peninusla; (2) the remote forested central highland and lowland regions of eastern Toliara Province between the Mahampaniny and Manampatrana Rivers, and between the Mangoro and the Namorona Rivers; (3) the north-western river basins in Mahajanga Province between the Tsaratanana massif and the basin of the Betsiboka River; (4) the western river basins in southwest Mahajanga Province; and (5) parts of the dry deciduous savanna region in central Toliara and western Fianarantsoa provinces.

The maps in figures 1-5 were prepared by S.K.R. using Arcview 8.1 GIS software. Many of the geocoordinates for species localities were taken from a database kindly provided to one of us (N.C.) by J.-M. Elouard. The specimens are deposited in the Field Museum of Natural History, Chicago, USA (FMNH).

The abbreviations used are: NHMW, Naturhistorisches Museum, Vienna, Austria; ZSM, Zoologische Staatssammlung, Munich, Germany; MNHN, Muséum national d'Histoire naturelle, Paris, France; $\mathrm{cw}$, the distance across the carapace at the widest point; cl, carapace length measured along the median line, from the anterior to the posterior margin; ch, carapace height, the maximum height of the cephalothorax; fw, front width, the width of the front measured along its anterior margin; coll., collected by; asl, above sea level.

Systematic account

FAMILY POTAMONAUTIDAE Bott, 1970

Hydrothelphusa A. Milne-Edwards, 1872

Hydrothelphusa agilis A. Milne-Edwards, 1872

(figure 2A)

Hydrothelphusa agilis A. Milne-Edwards, 1872: 2 (type locality: Madagascar, Sakaleone River); Rathbun, 1905: 266-268, figure 72, pl. 15, figure 7; Balss, 1929: 357; Pretzmann, 1961: 165; Cumberlidge, 1997: 584-585; Cumberlidge and Boyko, 2001: 126; Cumberlidge and Sternberg, 2002: 48, 50-51, figures 1A, 3A, 4A, 5A, 6A, 7A, B, 8A, 9A-D, 11A, tables $1-4$.

Hydrothelphusa agilis agilis Bott, 1965: 340-341, figure 4, pl. 2 figures 8, 9, pl. 4, figure 18; Rabeharisoa, 1996: 156-157. 


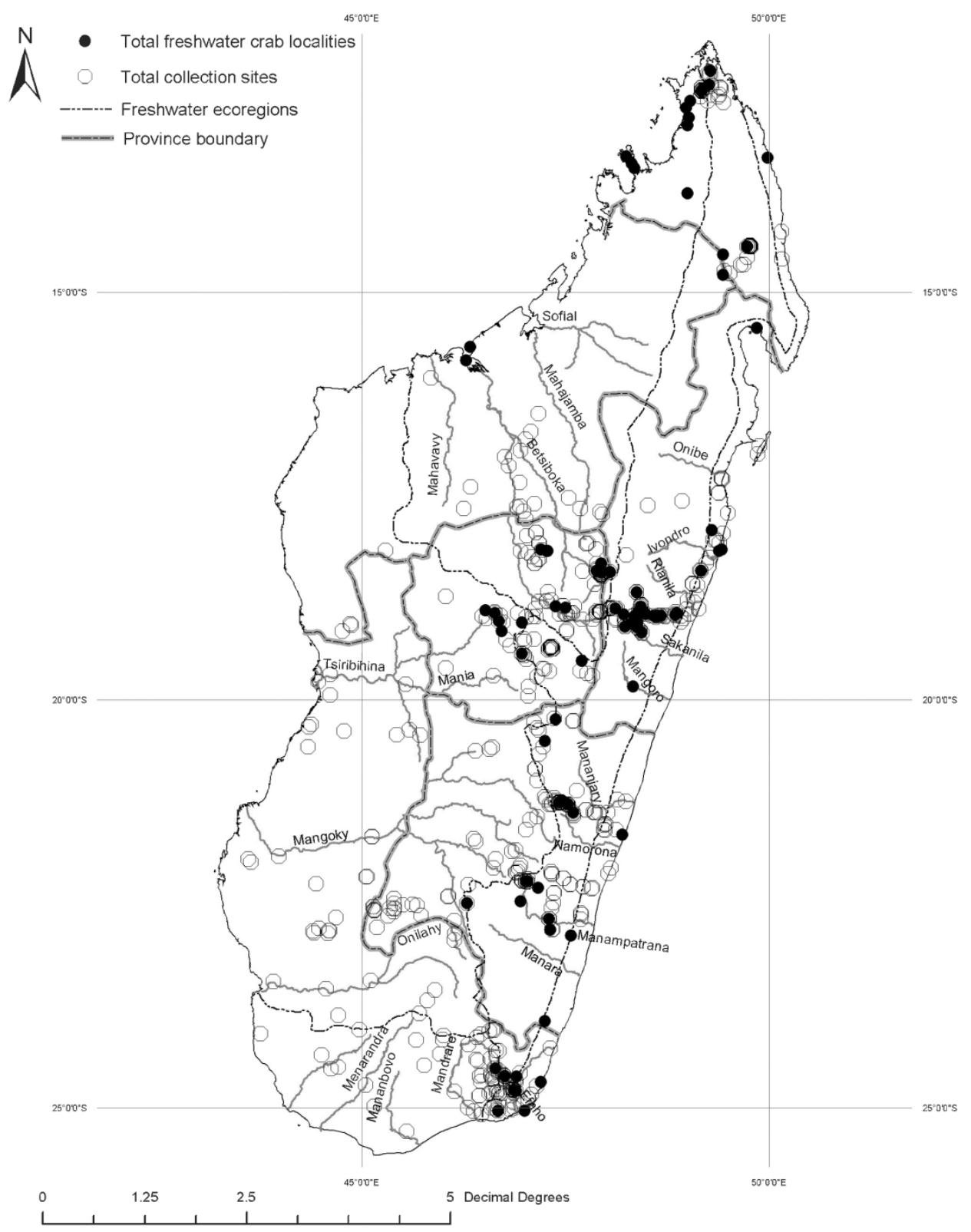

FIG. 1. Freshwater habitats surveyed by Elouard and colleagues (open circles). The localities where freshwater crabs were collected by Elouard and colleagues are marked by a black circle.

Material examined. All coll. J.-M. Elouard and colleagues (see Acknowledgements). Madagascar: one male (cw $23.8 \mathrm{~mm}$ ), Mangoro River, affluent of Tetivato River, basin of Mangoro River, Betafo, $840 \mathrm{~m}$ asl, $18^{\circ} 52^{\prime} 37^{\prime \prime} \mathrm{S}$, $48^{\circ} 06^{\prime} 55^{\prime \prime}$ E, 3 April 1992 (FMNH 5724). Four males (cws 18.3, 46.9, 50.6, $56.1 \mathrm{~mm}$ ), together with $H$. madagascariensis, affluent of Iantara River, basin of the Manampatrana River, Andringitra, $1370 \mathrm{~m}$ asl, $22^{\circ} 13^{\prime} 23^{\prime \prime} \mathrm{S}, \quad 47^{\circ} 01^{\prime} 53^{\prime \prime} \mathrm{E}$, 

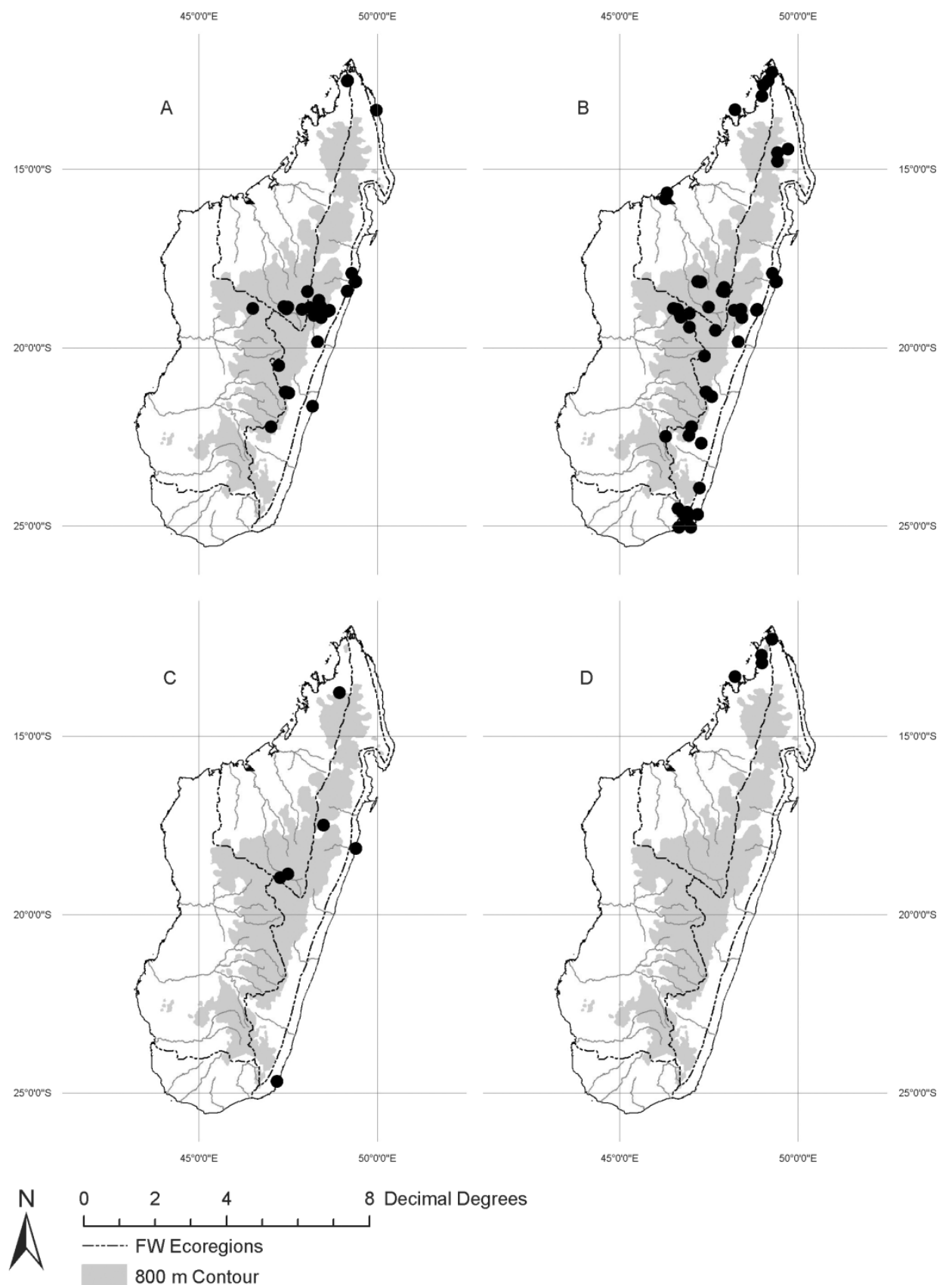

FIG. 2. Summaries of the known distribution of four species of Malagasy freshwater crabs belonging to the genera Hydrothelphusa and Madagapotamon. (A) H. agilis; (B) H. madagascariensis; (C) H. goudoti; (D) M. humberti. Black broken lines indicate freshwater ecoregion boundaries, shaded broken lines indicate provincial boundaries, and the shaded area indicates land at, and above, the $800 \mathrm{~m}$ contour. 
16 November 1993 (FMNH 5728). Two males (cws 22.3, $36.1 \mathrm{~mm}$ ), one adult female (cw $53.6 \mathrm{~mm}$ ), together with $H$. madagascariensis, Ambatandrano River, basin of the Namorona River Ambatandrano, $775 \mathrm{~m}$ asl, $21^{\circ} 14^{\prime} 45^{\prime \prime} \mathrm{S}, 47^{\circ} 26^{\prime} 32^{\prime \prime} \mathrm{E}, 17$ April 1994 (FMNH 5735). One juvenile male (cw $13.5 \mathrm{~mm}$ ), Vakoho River, basin of Sakanila River, Lakato road, $812 \mathrm{~m}$ asl, $1^{\circ} 06^{\prime} 25^{\prime \prime} \mathrm{S}, 4^{\circ} 23^{\prime} 12^{\prime \prime} \mathrm{E}, 21$ March 1995 (FMNH 5741). Two males (cws 19.8, $20 \mathrm{~mm}$ ) (FMNH 5743). Two males (cws 12.1, $21.5 \mathrm{~mm}$ ), basin of Rianila River, Lakato road, $1050 \mathrm{~m}$ asl, $19^{\circ} 03^{\prime} 07^{\prime \prime} \mathrm{S}, 48^{\circ} 21^{\prime} 38^{\prime \prime} \mathrm{E}$, 21 March 1995 (FMNH 5744). One juvenile, Makis River, basin of Antongombato River, base camp, $1075 \mathrm{~m}$ asl, 12 $31^{\prime} 40^{\prime \prime} \mathrm{S}, 49^{\circ} 10^{\prime} 09^{\prime \prime} \mathrm{E}, 31$ March 1995 (FMNH 5746). One juvenile, Makis River, basin of Antongombato River, Mt Ambre-Aval, $1040 \mathrm{~m}$ asl, 12 $2^{\circ} 31^{\prime} 31^{\prime \prime} \mathrm{S}, 49^{\circ} 10^{\prime} 22^{\prime \prime} \mathrm{E}, 1$ April 1995 (FMNH 5747). Two males (cws 23.2, $39.2 \mathrm{~mm}$ ), Sahatany River, basin of Rianila River, Périnet-Réserve, Parc National d'Andasibe-Mantadia, $935 \mathrm{~m}$ asl, 18 ${ }^{\circ} 51^{\prime} 10^{\prime \prime} \mathrm{S}, 48^{\circ} 25^{\prime} 39^{\prime \prime} \mathrm{E}, 13$ April 1995 (FMNH 5750). Three males (cws 14.2, 14.9, $22.8 \mathrm{~mm}$ ), camp on road to Lakato, $1075 \mathrm{~m}$ asl, $19^{\circ} 03^{\prime} 30^{\prime \prime} \mathrm{S}, 48^{\circ} 21^{\prime} 50^{\prime \prime} \mathrm{E}, 19$ October 1995 (FMNH 5756). Two males (cws 28.1, 35.2 mm), Manambolo River, basin of Ivondro River, Ampasimadinika, $44 \mathrm{~m}$ asl, $18^{\circ} 24^{\prime} 53^{\prime \prime} \mathrm{S}, 49^{\circ} 09^{\prime} 51^{\prime \prime} \mathrm{E}, 17$ January 1996 (FMNH 5761). One male (cw $20.1 \mathrm{~mm}$ ), Tsaratango River, basin of Namorona River, Tsaratango, $585 \mathrm{~m}$ asl, $21^{\circ} 16^{\prime} 33^{\prime \prime} \mathrm{S}, 47^{\circ} 31^{\prime} 50^{\prime \prime} \mathrm{E}, 8$ November 1996 (FMNH 5765). Four males (cws 14.4, $16.2,18.6,19.4 \mathrm{~mm}$ ), one juvenile (cw $<10 \mathrm{~mm}$ ), basin of Namorona River, Hotel Domaine nature, $21^{\circ} 15^{\prime} 07^{\prime \prime} \mathrm{S}, 4^{\circ} 26^{\prime} 36^{\prime \prime} \mathrm{E}, 6$ November 1996 (FMNH 5767). One male (cw $41.7 \mathrm{~mm}$ ), Tsaratango River, basin of Namorona River, $537 \mathrm{~m}$ asl, $21^{\circ} 16^{\prime} 20^{\prime \prime} \mathrm{S}, 47^{\circ} 31^{\prime} 35^{\prime \prime} \mathrm{E}, 13$ November 1996 (FMNH 5768). One male (cw $27.5 \mathrm{~mm}$ ), Sahatandra River, basin of Rianila River, Ambodirina, $980 \mathrm{~m}$ asl, $19^{\circ} 01^{\prime} 32^{\prime \prime} \mathrm{S}$, $48^{\circ} 20^{\prime} 28^{\prime \prime}$ E, 27 November 1996 (FMNH 5770). Three males (cws 17.7, 18.4, $19.7 \mathrm{~mm}$ ), basin of Rianila River, affluent of Sahatandra River, $1050 \mathrm{~m}$ asl, $19^{\circ} 02^{\prime} 22^{\prime \prime} \mathrm{S}, 48^{\circ} 21^{\prime} 51^{\prime \prime} \mathrm{E}, 22$ April 1997 (FMNH 5773). Two males (cws 15.2, $21.5 \mathrm{~mm}$ ), basin of Rianila River, Lakato road, $1050 \mathrm{~m}$ asl, $19^{\circ} 02^{\prime} 40^{\prime \prime} \mathrm{S}, 48^{\circ} 21^{\prime} 48^{\prime \prime} \mathrm{E}$, 22 April 1997 (FMNH 5774). One male (32.1 mm), Gri-Gri, Ilazana River, basin of Rianila River, 430 m, 18 $58^{\prime} 54^{\prime \prime S}$, 48 36'41'E, 24 April 1997 (FMNH 5775). One male (cw $32.2 \mathrm{~mm}$ ), Beharena River, basin of Betsiboka River, Antaniditra, $1370 \mathrm{~m}$ asl, $18^{\circ} 25^{\prime} 43^{\prime \prime} \mathrm{S}, 48^{\circ} 02^{\prime} 55^{\prime \prime} \mathrm{E}, 22$ November 1997 (FMNH 5777). One male (cw $17.8 \mathrm{~mm}$ ), basin of Rianila River, affluent of Sahatandra River, Moramanga, $800 \mathrm{~m}$ asl, 18 $56^{\prime} 27^{\prime \prime} \mathrm{S}, 4^{\circ} 29^{\prime} 12^{\prime \prime} \mathrm{E}, 22$ April 1998 (FMNH 5778). One juvenile, Sandrakatrana River, basin of Rianila River, Ambodiaviavy, $420 \mathrm{~m}$ asl, $18^{\circ} 57^{\prime} 50^{\prime \prime} \mathrm{S}$, 48 38'50'E, 30 April 1998 (FMNH 5779). One juvenile, Sandrakatrana River, basin

Fig. 3. Summaries of the known distribution of seven species of Malagasy freshwater crabs belonging to the genera Marojejy, Boreas, Malagasya and Skelosophusa. (A) Marojejy longimerus; (B) B. uglowi; (C) Malagasya antongilensis (circle), Malagasya goodmani (triangle); (D) S. gollhardi (cross); S. prolixa $(\times) ; S$. eumeces (circle). (C) Includes all known localities (17 different sites) between latitudes $12^{\circ}$ and $24^{\circ} \mathrm{S}$ for Malagasya antongilensis, all taken from the literature (Cumberlidge, 1997, 1998; Cumberlidge and Sternberg, 2002), and one locality for M. goodmani from Cumberlidge and Sternberg (2002). (D) Includes all known localities for Skelosophusa, all taken from the literature (Ng and Takeda, 1994; Cumberlidge and Sternberg, 2002). Data for Marojejy and Boreas are taken from the present study and from the literature (Cumberlidge and Sternberg, 2002). Black broken lines indicate freshwater ecoregion boundaries, shaded broken lines indicate provincial boundaries, and the shaded area indicates land at, and above, the $800 \mathrm{~m}$ contour. 

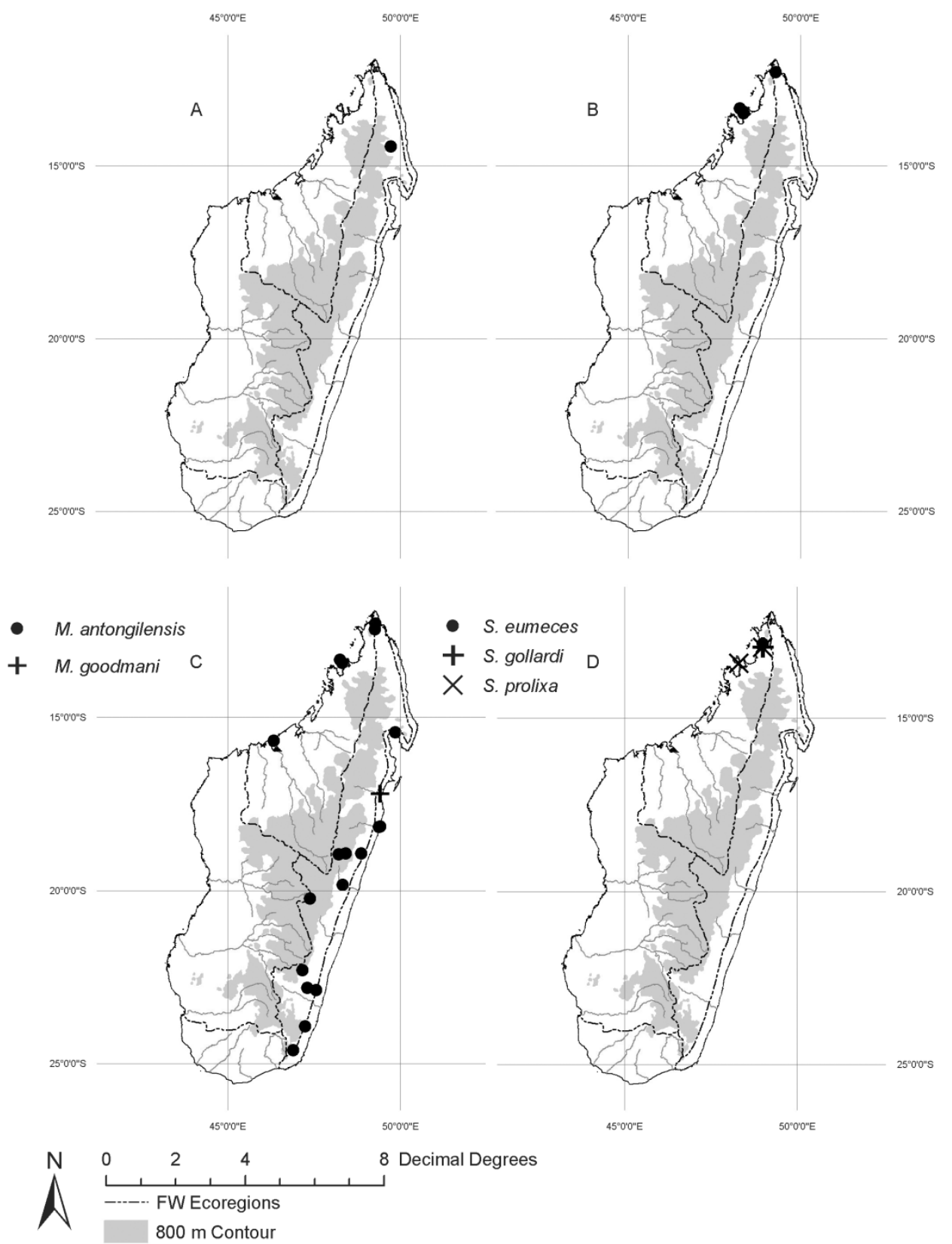

of Rianila River, Ambodaviavy, $325 \mathrm{~m}$ asl, 18 $8^{\circ} 57^{\prime} 45^{\prime \prime} \mathrm{S}, 48^{\circ} 40^{\prime} 16^{\prime \prime} \mathrm{E}, 30$ April 1998 (FMNH 5780). Two males (cws 18.9, $21.2 \mathrm{~mm}$ ), one juvenile (cw $<10 \mathrm{~mm}$ ), basin of Rianila River, Périnet-Réserve, Parc National d'Andasibe-Mantadia, $900 \mathrm{~m}$ asl, $18^{\circ} 52^{\prime} 39^{\prime \prime} \mathrm{S}, 48^{\circ} 25^{\prime} 29^{\prime \prime} \mathrm{E}, 30$ May 1998 (FMNH 5781). One juvenile, 17, $15 \mathrm{~km}$ east of Morarano, basin of Rianila River, $980 \mathrm{~m}$ asl, $18^{\circ} 40^{\prime} 32^{\prime \prime} \mathrm{S}, 48^{\circ} 22^{\prime} 21^{\prime \prime} \mathrm{E}$ (FMNH 5782). Three juveniles, Makis River, basin of Antongombato River, northern affluent, $990 \mathrm{~m}$ asl, $12^{\circ} 30^{\prime} 54^{\prime \prime} \mathrm{S}, 49^{\circ} 10^{\prime} 47^{\prime \prime} \mathrm{E}, 19$ March 1999 (FMNH 5783). One juvenile, 
camp on road to Lakato, basin of Rianila River, $75 \mathrm{~m}$ asl, $19^{\circ} 03^{\prime} 30^{\prime \prime} \mathrm{S}, 48^{\circ} 21^{\prime} 50^{\prime \prime} \mathrm{E}$, 15 October 1998 (FMNH 5784). One male (cw $15.6 \mathrm{~mm}$ ), Lakato road, basin of Rianila River, $1050 \mathrm{~m}$ asl, $19^{\circ} 02^{\prime} 40^{\prime \prime} \mathrm{S}, 48^{\circ} 21^{\prime} 48^{\prime \prime} \mathrm{E}, 16$ October 1998 (FMNH 5785). Two males (cws 21.4, 26.2 mm), Moramanga, basin of Mangoro River, $940 \mathrm{~m}$ asl, $19^{\circ} 05^{\prime} 57^{\prime \prime} \mathrm{S}, 48^{\circ} 14^{\prime} 13^{\prime \prime} \mathrm{E}, 23$ October 1998 (FMNH 5787). One male (cw $21.6 \mathrm{~mm}$ ), Anosibe An'ala, basin of Mangoro River, $960 \mathrm{~m}$ asl, $19^{\circ} 05^{\prime} 53^{\prime \prime} \mathrm{S}, 48^{\circ} 14^{\prime} 00^{\prime \prime} \mathrm{E}$, 23 October 1998 (FMNH 5788). One male (cw $23 \mathrm{~mm}$ ), three juveniles (cw $<10 \mathrm{~mm}$ ), Lakato road, basin of Rianila River, $1050 \mathrm{~m}$ asl, $19^{\circ} 03^{\prime} 07^{\prime \prime} \mathrm{S}, 48^{\circ} 21^{\prime} 38^{\prime \prime} \mathrm{E}, 26$ October 1998 (FMNH 5789). One male (cw $21.7 \mathrm{~mm}$ ), Sahatandra River, cascade de Lakato, basin of Rianila River, $975 \mathrm{~m}$ asl, $19^{\circ} 01^{\prime} 35^{\prime \prime} \mathrm{S}, 48^{\circ} 20^{\prime} 39^{\prime \prime} \mathrm{E}, 26$ October 1998 (FMNH 5790 ). Four juveniles, Lakato road, basin of Rianila River, $1050 \mathrm{~m}$ asl, $19^{\circ} 02^{\prime} 40^{\prime \prime} \mathrm{S}$, $48^{\circ} 21^{\prime} 48^{\prime \prime}$ E, 27 October 1998 (FMNH 5791). One male (cw $27.3 \mathrm{~mm}$ ), Sahatandra River, $200 \mathrm{~m}$ before the bridge, basin of Rianila River, $1050 \mathrm{~m}$ asl, $19^{\circ} 02^{\prime} 40^{\prime \prime} \mathrm{S}$, $48^{\circ} 21^{\prime} 43^{\prime \prime}$ E, 27 October 1998 (FMNH 5792). Four males (cws 28.1, 28.8, 29, $30.5 \mathrm{~mm}$ ) (FMNH 5793). Five juveniles, $15 \mathrm{~km}$ east of Morarano, basin of Rianila River, $975 \mathrm{~m}$ asl, $18^{\circ} 40^{\prime} 35^{\prime \prime} \mathrm{S}, 48^{\circ} 22^{\prime} 21^{\prime \prime} \mathrm{E}, 7$ November 1998 (FMNH 5794). Two males (cws 11.7, $26.1 \mathrm{~mm}$ ), $15 \mathrm{~km}$ east of Morarano, basin of Rianila River, $980 \mathrm{~m}$

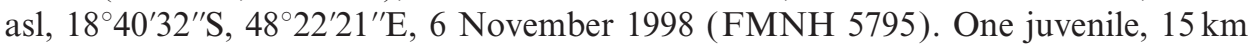
east of Morarano, basin of Rianila River, $975 \mathrm{~m}$ asl, $18^{\circ} 40^{\prime} 35^{\prime \prime} \mathrm{S}, 48^{\circ} 22^{\prime} 21^{\prime \prime} \mathrm{E}$, 7 November 1998 (FMNH 5796). One male (cw $21 \mathrm{~mm}$ ), one juvenile ( $\mathrm{cw}<10 \mathrm{~mm}$ ), camp on road to Lakato, basin of Rianila River, $1075 \mathrm{~m}$ asl, $19^{\circ} 03^{\prime} 30^{\prime \prime} \mathrm{S}, 48^{\circ} 21^{\prime} 50^{\prime \prime} \mathrm{E}$, 17 November 1998 (FMNH 5797). Two males (cws 14.4, $22.5 \mathrm{~mm}$ ), five juveniles (cws $<10 \mathrm{~mm}$ ), Lakato road, basin of Rianila River, $1050 \mathrm{~m}$ asl, $19^{\circ} 02^{\prime} 40^{\prime \prime} \mathrm{S}$, 48²1'48”'E, 18 November 1998 (FMNH 5798). Two males (cws 16.9, 17.3 mm), five juveniles (cws $<10 \mathrm{~mm}$ ), road to Lakato, basin of Rianila River, $0 \mathrm{~m}$ asl, $19^{\circ} 03^{\prime} 31^{\prime \prime} \mathrm{S}$, $48^{\circ} 21^{\prime} 52^{\prime \prime} \mathrm{E}, 19$ November 1998 (FMNH 5799). One juvenile, camp on road to Lakato, $19^{\circ} 03^{\prime} 30^{\prime \prime} \mathrm{S}, 48^{\circ} 21^{\prime} 50^{\prime \prime} \mathrm{E}, 19$ October 1995 (FMNH 5800). One juvenile, camp on road to Lakato, basin of Rianila River, $1075 \mathrm{~m}$ asl, $19^{\circ} 03^{\prime} 30^{\prime \prime} \mathrm{S}, 48^{\circ} 21^{\prime} 50^{\prime \prime} \mathrm{E}$, 10 December 1998 (FMNH 5801). Four males (cws 14.1, 16.8, 17.6, $21.7 \mathrm{~mm}$ ), Iantara River, basin of Manampatrana River, Andringitra, camp I, $1350 \mathrm{~m}$ asl, $22^{\circ} 13^{\prime} 28^{\prime \prime} \mathrm{S}, 47^{\circ} 01^{\prime} 50^{\prime \prime} \mathrm{E}, 17$ November 1993 (FMNH 5810). One male (cw $26.8 \mathrm{~mm}$ ), one juvenile (cw $<10 \mathrm{~mm}$ ) Lakato road, basin of Rianila River, $1050 \mathrm{~m}$ asl, $19^{\circ} 02^{\prime} 40^{\prime \prime} \mathrm{S}, 48^{\circ} 21^{\prime} 48^{\prime \prime} \mathrm{E}, 18$ November 1998 (FMNH 5811).

All coll. S. M. Goodman. One male (cw $44.9 \mathrm{~mm}$ ), Amaringilra, 20 November 1993 (FMNH 5713). One male (cw $21.2 \mathrm{~mm}$ ) (FMNH 5714). One juvenile (FMNH 5717). Three males (cws 42.1, 42.6, $42.7 \mathrm{~mm}$ ) (FMNH 5719). Two males (cws 17.5, $30.6 \mathrm{~mm}$ ) basin of Rianila River, $1^{\circ} 02^{\prime} 49^{\prime \prime} \mathrm{S}, 48^{\circ} 21^{\prime} 55^{\prime \prime} \mathrm{E}, 16$ March 1995 (FMNH 5740 ). One male (cw $17.6 \mathrm{~mm}$ ), basin of Rianila River, Lakato road, $18^{\circ} 58^{\prime} 17^{\prime \prime} \mathrm{S}$, $48^{\circ} 21^{\prime} 03^{\prime \prime} \mathrm{E}, 19$ October 1995 (FMNH 5757). Four males (cws 17.2, 18.2, 18.5, $23.4 \mathrm{~mm}$ ), one juvenile (cw $<10 \mathrm{~mm}$ ) (FMNH 5806). Five males (cws 20.1, 24.6, 25, 25.3, $29.1 \mathrm{~mm})$ (FMNH 5807).

Distribution. Hydrothelphusa agilis is found in the streams and rivers mainly in the northern, central and south-eastern regions of the island (in Fianarantsoa, Antananarivo, Toamasina and Antsiranana Provinces) (figure 2A). Figure 2A includes a total of 53 different localities for $H$. agilis from the present study and from the literature (Rabeharisoa, 1996; Cumberlidge, 1997; Cumberlidge and Boyko, 2001; Cumberlidge and Sternberg, 2002). Hydrothelphusa agilis is found in the rivers and streams of eight major river basins in five out of six Madagascan provinces in latitudes between $12^{\circ}$ and $22^{\circ} \mathrm{S}$, and from a lake near Mandraka, Toamasina Province 
(Cumberlidge and Sternberg, 2002). These river drainages are Antongombato (Antsiranana Province), Betsiboka (Antananarivo Province), Namorona and Manampatrana (Fianarantsoa Province), and Rianila, Mangoro, Ivondro and Sakanila (Toamasina Province). There are no records for this species from Mahajanga Province. The localities in the Betsiboka river basin are all at high elevations (1220-1370 m asl) in the clean fast-flowing tributaries of the highlands of Antananarivo Province. Hydrothelphusa agilis has been collected from a range of elevations from sea level (a stream in the drainage of the Rianila River) to $1800 \mathrm{~m}$ asl in the headwaters of the Tsiribihina River.

Remarks. Hydrothelphusa agilis is a large and common species, whose adult size ranges from carapace widths of $45-76 \mathrm{~mm}$. The frontal margin of its carapace is diagnostic: horizontal and undeflexed, deeply indented and distinctly toothed. In addition, the suborbital margin is strongly toothed, as is the cheliped ischium. All of these characters serve to separate it from the three other species in the genus. Hydrothelphusa agilis is sympatric with $H$. madagascariensis in the Ambatandrano River in the Manampatrana river basin in Andringitra $(775 \mathrm{~m}$ asl), and in the Iantara River (1370 m asl) (FMNH 5728, 5735).

Conservation status. Hydrothelphusa agilis is a widespread and abundant species, has been collected recently and its conservation status is secure (table 1). This species is found in a number of protected areas including the Parc National d'AndasibeMantadia (Périnet-Réserve), the Parc National de Ranomafana, the Parc National d'Andringitra and the Parc National de la Montagne d'Ambre.

Hydrothelphusa madagascariensis (A. Milne-Edwards, 1872)

(figure 2B)

Thelphusa madagascariensis A. Milne-Edwards, 1872: 1 (type locality: Sakaleone River, near Bombetok, Madagascar).

Potamon (Potamon) madagascariensis Rathbun, 1904: 264, figure 7, pl. 9, figure 9; Balss, 1929: 254.

Potamon (Potamon) humbloti Rathbun, 1904: 211-219, pl. 12, figure 10 (type locality: Madagascar).

Potamon (Potamon) grandidieri Rathbun, 1904: 298, figure 29, pl. 12, figure 11; Balss, 1929: 354 (type locality: Madagascar).

Potamon (Potamon) bombetokensis Rathbun, 1904: 298-299, pl. 12, figure 6; Balss, 1929: 354 (type locality: Bombetok, Madagascar).

Bottia madagascariensis Pretzmann, 1961: 163, figure 2.

Bottia madagascariensis reticulata Pretzmann, 1961: 163, figure 2 (type locality: Androkabe-Bach, near Fort Dauphin (=Tolagnaro), Madagascar).

Bottia bombetokensis Pretzmann, 1961: 164, figure 4.

Hydrothelphusaagilis madagascariensis Bott, 1965: 341-342, pl. 3, figures 10, 11; Rabeharisoa, 1996: 156-157.

Hydrothelphusa humbloti Bott, 1965: 342-344, not pl. 3, figures 12, 13, not figures 5, 6; Cumberlidge, 1997: 585 .

Hydrothelphusa madagascariensis Cumberlidge, 1997: 585; 1998: 209; Cumberlidge and Boyko, 2001: 126-127; Cumberlidge and Sternberg, 2002: 51-54, figures 1B, 3B, 4B, 5B, 6B, 7C, $\mathrm{D}, 8 \mathrm{~B}, 9 \mathrm{E}-\mathrm{I}, 11 \mathrm{~B}$ )

Hydrothelphusa bombetokensis Cumberlidge and Sternberg, 2002: 54-56, figures 1C, 3C, 4C, 5C, 6C, 7E, F, 8C, 9N-Q, 11C, tables 1-4.

Material examined. All coll. J.-M. Elouard and colleagues (see Acknowledgements). Madagascar: one juvenile male (cw $22.5 \mathrm{~mm}$ ), Antananarivo Province, Réserve Spéciale d'Ambohitantely, jardin botanique, $24 \mathrm{~km}$ north-east of Ankazobe, $1450 \mathrm{~m}, 18^{\circ} 10^{\prime} 1^{\prime \prime} \mathrm{S}, 47^{\circ} 16^{\prime} 6^{\prime \prime} \mathrm{E}, 15$ December 1997 (FMNH 5472). One 
Table 1. Checklist of native Malagasy freshwater crabs and their region(s) of occurrence modified from Sparks and Stiassny (in press) (the five major ecoregions listed correspond to those discussed in the text).

\begin{tabular}{|c|c|c|c|c|c|c|c|c|c|}
\hline Family & Genus & Species & $\begin{array}{c}\text { Year } \\
\text { described }\end{array}$ & $\begin{array}{l}\text { Conservation } \\
\text { status }\end{array}$ & $\begin{array}{c}\text { North- } \\
\text { western } \\
\text { basins }\end{array}$ & $\begin{array}{l}\text { Eastern } \\
\text { highlands }\end{array}$ & $\begin{array}{l}\text { Eastern } \\
\text { lowlands }\end{array}$ & $\begin{array}{c}\text { Western } \\
\text { basins }\end{array}$ & $\begin{array}{c}\text { Southern } \\
\text { basins }\end{array}$ \\
\hline Potamonautidae & Hydrothelphusa & agilis & 1872 & $\mathrm{~S}$ & $\mathrm{X}$ & $\mathrm{X}$ & $\mathrm{X}$ & $*$ & - \\
\hline Potamonautidae & Hydrothelphusa a & goudoti & 1853 & $\mathrm{~T}$ & - & $\mathrm{X}$ & $\mathrm{X}$ & $*$ & - \\
\hline Potamonautidae & Madagapotamon & humberti & 1965 & $\mathrm{R}$ & $\mathrm{X}$ & - & - & - & - \\
\hline Potamonautidae & Marojejy & longimerus & 2002 & $\mathrm{R}$ & - & $\mathrm{X}$ & - & - & - \\
\hline Potamonautidae & Skelosophusa & gollardi & 1965 & $\mathrm{R}$ & $\mathrm{X}$ & - & - & - & - \\
\hline Potamonautidae & Skelosophusa & prolixa & 1994 & $\mathrm{R}$ & $\mathrm{X}$ & - & - & - & - \\
\hline Potamonautidae & Skelosophusa & eumeces & 1994 & $\mathrm{R}$ & $\mathrm{X}$ & - & - & - & - \\
\hline Total & & & & & 8 & 5 & 5 & 0 & 0 \\
\hline
\end{tabular}

Conservation status abbreviations: $\mathrm{S}$, secure; $\mathrm{T}$, threatened; $\mathrm{R}$, extremely rare/highly endangered.

An $\mathrm{X}$ indicates presence of a species in a particular ecoregion; *indicates presence in headwaters only. Totals for each column are presented at the bottom of the table. 
juvenile female (cw $19.7 \mathrm{~mm}$ ) affluent of Ihazofotsy River, basin of Onilahy River, near Inabinda, 11 April 1992 (FMNH 5712). One female (cw $50.1 \mathrm{~mm}$ ), one male (cw $44 \mathrm{~mm}$ ), together with H. goudoti (FMNH 5720). One juvenile (FMNH 5722). One juvenile male (cw $24.3 \mathrm{~mm}$ ), basin of Rianila River, Sahatiravona River, $25 \mathrm{~m}$

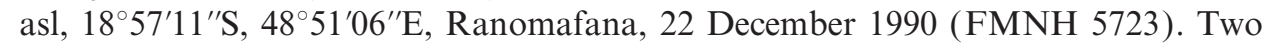
juvenile males (cws 25.5, $27.8 \mathrm{~mm}$ ), two juvenile females (cws 23.3, $23.4 \mathrm{~mm}$ ), affluent of Namorona River, basin of Namorona River, Ranomafana, $820 \mathrm{~m}$ asl, $21^{\circ} 14^{\prime} 57^{\prime \prime} \mathrm{S}$, $47^{\circ} 25^{\prime} 32^{\prime \prime} \mathrm{E}, 14$ November 1993 (FMNH 5727). One juvenile female (cw 18.3), three males (cws 46.9, 50.6, $56.1 \mathrm{~mm}$ ), Lantara River, basin of Manampatrana River, Andringitra, $1370 \mathrm{~m}$ asl, together with $H$. agilis, $22^{\circ} 13^{\prime} 23^{\prime \prime} \mathrm{S}, 47^{\circ} 01^{\prime} 53^{\prime \prime} \mathrm{E}$, 16 November 1993 (FMNH 5728). Four males (cws 17.1, 23.5, 25.2, $31.2 \mathrm{~mm}$ ), five females (cws 18.3, 27.1, 28, 28.8, $32.1 \mathrm{~mm}$ ), Sahavatov River, basin of Manampatrana River, Andringitra camp II, $1390 \mathrm{~m}$ asl, 22 $13^{\prime} 33^{\prime \prime} \mathrm{S}, 47^{\circ} 00^{\prime} 50^{\prime \prime} \mathrm{E}, 20$ November 1993 (FMNH 5730). Two males (cws 23.8, $29.7 \mathrm{~mm}$ ), one female (cw $32.9 \mathrm{~mm})$ (FMNH 5731). One subadult female (cw $24.2 \mathrm{~mm}$ ), together with $H$. agilis, Ambatandrano River, Ambatandrano, $21^{\circ} 14^{\prime} 45^{\prime \prime} \mathrm{S}, 47^{\circ} 26^{\prime} 32^{\prime \prime} \mathrm{E}, 17$ April 1994 (FMNH 5735). Five males (cws 13.6, 15, 17.6, 18.3, 19.1 mm), Namorona River, basin of Namorona River, lfanadiana-Tolongoina road, $500 \mathrm{~m}$ asl, 21 ${ }^{\circ} 22^{\prime} 40^{\prime \prime} \mathrm{S}, 47^{\circ} 35^{\prime} 55^{\prime \prime} \mathrm{E}, 22$ April 1994 (FMNH 5737). One female (cw $38 \mathrm{~mm}$ ), basin of Efaho River, Ranopiso Iambany, $45 \mathrm{~m}$ asl, $25^{\circ} 02^{\prime} 13^{\prime \prime} \mathrm{S}, 46^{\circ} 40^{\prime} 23^{\prime \prime} \mathrm{E}, 15$ May 1994 (FMNH 5745). One male (cw $33.9 \mathrm{~mm}$ ), Sahambano River, basin of Mananara-sud River, $570 \mathrm{~m}$ asl, $22^{\circ} 29^{\prime} 21^{\prime \prime} \mathrm{S}$, 46 $17^{\prime} 37^{\prime \prime}$ E, 25 May 1995 (FMNH 5748). One female (cw $43.2 \mathrm{~mm}$ ), Manampatrana River, basin of Manampatrana River, Mahazoalala village, $170 \mathrm{~m}$ asl, $22^{\circ} 40^{\prime} 55^{\prime \prime} \mathrm{S}$, 47¹7'49"E, 18 June 1995 (FMNH 5749). Two males (cws 20.4, $22.9 \mathrm{~mm}$ ), one female (cw $25.8 \mathrm{~mm}$ ), Mazy River, affluent of the Sakay River, basin of Tsiribihina River, Réserve Naturelle Intégrale d'Amparaky, $975 \mathrm{~m}$ asl, $18^{\circ} 56^{\prime} 03^{\prime \prime} \mathrm{S}, 46^{\circ} 38^{\prime} 07^{\prime \prime} \mathrm{E}$, 11 October 1995 (FMNH 5752). One male (cw $18.9 \mathrm{~mm}$ ), Lily River, affluent of Mahajilo River, basin of Tsiribihina River, Antafofo, $1100 \mathrm{~m}$ asl, $19^{\circ} 01^{\prime} 43^{\prime \prime} \mathrm{S}$, $46^{\circ} 41^{\prime} 07^{\prime \prime}$ E, 8 October 1995 (FMNH 5753). One male, Ambatomisana River, basin of Betsiboka River, Geranium-usine, 18 $27^{\prime} 03^{\prime \prime} \mathrm{S}$, 47 $56^{\prime} 47^{\prime \prime} \mathrm{E}, 18$ October 1995 (FMNH 5754). One male (cw $44.5 \mathrm{~mm}$ ), one female (cw $41.7 \mathrm{~mm}$ ), Vanjainanitra River, basin of Betsiboka River, Amboasary, $1300 \mathrm{~m}$ asl, $18^{\circ} 26^{\prime} 03^{\prime \prime} \mathrm{S}, 47^{\circ} 56^{\prime} 40^{\prime \prime} \mathrm{E}$, 25 October 1995 (FMNH 5755). One juvenile male (cw $17.5 \mathrm{~mm}$ ), Ambahibe River, basin of Efaho River, Isaka-Ivondro, $70 \mathrm{~m}$ asl, $24^{\circ} 46^{\prime} 47^{\prime \prime} \mathrm{S}, 46^{\circ} 51^{\prime} 53^{\prime \prime} \mathrm{E}, 20$ November 1995 (FMNH 5758). Seven subadult males (cws 20.8, 25.2, 28.2, 28.6, 32.3, 32.8, $34.8 \mathrm{~mm}$ ), four subadult females (cws 27.5, 28.2, 29.6, $32.8 \mathrm{~mm}$ ) Betoreo River, basin of Efaho River, $115 \mathrm{~m}$ asl, $24^{\circ} 47^{\prime} 20^{\prime \prime} \mathrm{S}, 46^{\circ} 53^{\prime} 48^{\prime \prime} \mathrm{E}, 24$ November 1995 (FMNH). One juvenile male (cw $23.7 \mathrm{~mm}$ ), two juvenile females (cws 21.4, $23.8 \mathrm{~mm}$ ), affluent of Andranohela River, basin of Manampanihy River, camp I Andohahela, $575 \mathrm{~m}$

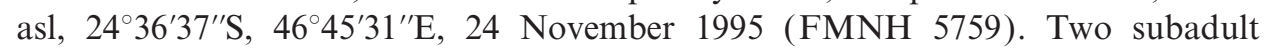
females (cws 25.7, $33.2 \mathrm{~mm}$ ), Sakamalio River, basin of Mandrare River, Andohahela, $480 \mathrm{~m}$ asl, 24 $31^{\circ} 03^{\prime \prime} \mathrm{S}, 46^{\circ} 38^{\prime} 32^{\prime \prime} \mathrm{E}, 2$ February 1996 (FMNH 5762). One male (cw $37.6 \mathrm{~mm}$ ), Sahaomby River, basin of Tsiribihina River, Manatoloza, $1800 \mathrm{~m}$ asl, $19^{\circ} 25^{\prime} 50^{\prime \prime} \mathrm{S}, 46^{\circ} 57^{\prime} 53^{\prime \prime} \mathrm{E}, 21$ May 1996 (FMNH 5763). One juvenile male (cw $20.8 \mathrm{~mm}$ ), Vanjainanitra River, basin of Betsiboka River, Amboasary, $1300 \mathrm{~m}$ asl, $18^{\circ} 26^{\prime} 03^{\prime \prime} \mathrm{S}, 47^{\circ} 56^{\prime} 40^{\prime \prime} \mathrm{E}, 31$ October 1996 (FMNH 5764). One juvenile male (cw $24.8 \mathrm{~mm}$ ), Sahaomby River, basin of Tsiribihina River, Manatoloza, $1800 \mathrm{~m}$ asl, $19^{\circ} 02^{\prime} 50^{\prime \prime} \mathrm{S}, 46^{\circ} 57^{\prime} 53^{\prime \prime} \mathrm{E}, 14$ November 1996 (FMNH 5769). One juvenile male (cw $19.8 \mathrm{~mm}$ ), Mananara River, basin of Betsiboka River, Anjozorobe, $18^{\circ} 24^{\prime} 47^{\prime \prime} \mathrm{S}$, 
47 52'53'E, $1220 \mathrm{~m}$ asl, 16 November 1996 (FMNH 5771). Three males (cws 13, 13.3, $26.2 \mathrm{~mm}$ ), Mananta River, basin of Namorona River, Mananta, $18^{\circ} 19^{\prime} 17^{\prime \prime} \mathrm{S}$, 47 56'27"E, 19 November 1996 (FMNH 5772). Two juveniles, Makis River, basin of Antongombato River, base camp, $1030 \mathrm{~m}$ asl, 19 March 1999, 12³1'27'S, $49^{\circ} 10^{\prime} 21^{\prime \prime} \mathrm{E}$ (FMNH 5804). Two males (cws 11.2, $11.3 \mathrm{~mm}$ ) Makis River, basin of Antongombato River, $1050 \mathrm{~m}$ asl, $49^{\circ} 10^{\prime} 21^{\prime \prime} \mathrm{E}$ (FMNH 5805).

All coll. S. M. Goodman. Fifteen specimens, Fianarantsoa Province, camp I, exterior of northern limit of Réserve Spéciale du Pic d'Ivohibe, $7 \mathrm{~km}$ east-north-east of Ivohibe, $22^{\circ} 28^{\prime} 2^{\prime \prime} \mathrm{S}, 4^{\circ} 57^{\prime} 6^{\prime \prime} \mathrm{E}, 900 \mathrm{~m}$ asl, along Ilefitany River, 1997 (FMNH 5464). Five adult females (cws 52.5, 53.1, 53.4, 54.2, 59.4 mm), two subadult females (cws 45.3, $49 \mathrm{~mm}$ ), one adult male (cw $61.9 \mathrm{~mm}$ ), one subadult male (cw $41.5 \mathrm{~mm}$ ), two juvenile males (cws 25.7, $31 \mathrm{~mm}$ ), Antananarivo Province, Réserve Spéciale d'Ambohitantely, $24 \mathrm{~km}$ NE Ankazobe, $1450 \mathrm{~m}, 18^{\circ} 10.1^{\prime} \mathrm{S}, 47^{\circ} 16.6^{\prime} \mathrm{E}, 15$ December 1997 (FMNH 5471). One juvenile (FMNH 5802). One male (cw $10.4 \mathrm{~mm})(\mathrm{FMNH}$ 5808). One male (cw $43.6 \mathrm{~mm}$ ), peach fur on dorsal carapace, Marojejy, camp I, $600 \mathrm{~m}$ asl, $14^{\circ} 26^{\prime} \mathrm{S}, 49^{\circ} 44^{\prime} \mathrm{E}$ (FMNH 6632). Three males (cws 38.6, 48.4, $49.9 \mathrm{~mm}$ ), east of Anjanaharibe, $1600 \mathrm{~m}$ asl, western slopes of the massif d'Anjanaharibe-Sud (Antsiranana Province), site 1, $13.5 \mathrm{~km}$ south-west of Befingotra, $14^{\circ} 47^{\prime} 0^{\prime \prime} \mathrm{S}$, $49^{\circ} 26^{\prime} 5^{\prime \prime} \mathrm{E}, 1200 \mathrm{~m}$ asl, along Analabe River, 25 October to 2 November 1999 (FMNH 6633). One male (cw $49.8 \mathrm{~mm}$ ), one female (cw $47.7 \mathrm{~mm}$ ), Marojejy, camp III, $800 \mathrm{~m}$ asl (FMNH 6634). One male (cw $48.6 \mathrm{~mm}$ ), peach fur on carapace, east of Anjanaharibe, western slopes of the massif d'Anjanaharibe-Sud (Antsiranana Province), camp site I, $800 \mathrm{~m}$ asl, $13.5 \mathrm{~km}$ south-west of Befingotra, $14^{\circ} 47^{\prime} 0^{\prime \prime} \mathrm{S}$, $49^{\circ} 26^{\prime} 5^{\prime \prime} \mathrm{E}, 1200 \mathrm{~m}$ asl, along Analabe River, 25 October to 2 November 1999 (FMNH 6636). Four males (cws 39.8, 48.8, 53.8, $56.8 \mathrm{~mm}$ ) east of Anjanaharibe (Antsiranana Province), $1200 \mathrm{~m}$ asl (FMNH 6637). One male (cw $33.3 \mathrm{~mm}$ ), Marojejy, camp III, $1200 \mathrm{~m}$ asl, $14^{\circ} 26^{\prime} \mathrm{S}, 49^{\circ} 44^{\prime} \mathrm{E}$ (FMNH 6638). One male (cw $45.2 \mathrm{~mm}$ ), Betaolana forest, $800 \mathrm{~m}$ asl, site $1,8.5 \mathrm{~km}$ north-west of Ambodiangezoka, along Ambolokopatrika River (Antsiranana Province), $820 \mathrm{~m}$ asl, $14^{\circ} 32^{\prime} 3^{\prime \prime} \mathrm{S}$, 49 $26^{\prime} 3^{\prime \prime}$ E, 7-14 October 1999 (FMNH 6639).

Distribution. Hydrothelphusa madagascariensis is the commonest and most widely distributed species of freshwater crab in Madagascar. It is found in the streams and rivers of the central highlands in all six provinces, from Tolagnaro in the south to Antsiranana in the north (figure 2B). Figure 2B includes a total of 53 different localities for $H$. madagascariensis from the present study and from the literature (Rabeharisoa, 1996; Cumberlidge, 1997, 1998; Cumberlidge and Boyko, 2001; Cumberlidge and Sternberg, 2002). Hydrothelphusa madagascariensis is sympatric with $H$. agilis (FMNH 5728, 5735) and with H. goudoti (FMNH 5720). Hydrothelphusa madagascariensis is found mainly in the headwaters of 10 major river basins in five Malagasy provinces in latitudes between $12^{\circ}$ and $25^{\circ} \mathrm{S}$. These are the basins of the Antongombato (Antsiranana Province), Betsiboka and Tsiribihina (Antananarivo Province), Namorona, Manampatrana and Mananara-Sud (Fianarantsoa Province), Rianila (Toamasina Province), and the Efaho, Mandrare and Manampanihy (Toliara Province) Rivers. Hydrothelphusa madagascariensis has been collected from a range of elevations from $25 \mathrm{~m}$ asl (in a stream in the basin of the Rianila River) to $1390 \mathrm{~m}$ asl in the Andringitra massif. The southern localities in Toliara Province are close to the limits of the humid forest biome, and crabs are absent from the xerophytic zone which begins to the west of the Anosyennes Mountains. The headwaters of the Mandrare River in Toliara Province flow through 
humid forest, but the lower section of the river passes through arid spiny bush country, its river bed is seasonally dry, and crabs are therefore absent.

Conservation status. Hydrothelphusa madagascariensis is a widespread and abundant species. It has been collected recently, and its conservation status is secure (table 1). This species is found in three protected areas in Antsiranana Province (the Réserve Spéciale de 1'Anjanaharibe-Sud, the Réserve Spéciale de l'Ankarana and the Parc National de Marojejy). It is also found in two protected areas in Antananarivo Province (the Réserve naturelle Intégrale d'Amparaky and the Réserve Spéciale d'Ambohitantely) and three in Fianarantsoa Province (the Parc National de Ranomafana, the Parc National d'Andringitra and the Réserve Spéciale du Pic d'Ivohibe).

Remarks. Hydrothelphusa madagascariensis was redescribed by Cumberlidge and Sternberg (2002) from the largest male paralectotype, a subadult (MNHN-B 4352) from the Sakaleone River near Bombetok in the central highland region $\left(20^{\circ} 34^{\prime} \mathrm{S}\right.$, $47^{\circ} 49^{\prime} \mathrm{E}$ ). This specimen has distinct fields of granulations in the anterolateral regions of the dorsal carapace, and on the suborbital and pterygostomial regions of the carapace sidewall, and has a row of large raised granules on both inferior margins of the merus of pereiopod 1. The major dactylus of the cheliped of this subadult specimen is not strongly arched and the dentition on the propodus is small and unremarkable. Potamon (Potamon) bombetokensis was described by Rathbun (1904) from an adult male, cw $50.1 \mathrm{~mm}$ (MNHN-B 6396), from Bombetok in the central highland region of Madagascar. This specimen has faint granulations in the anterolateral regions of the dorsal carapace, and on the suborbital and pterygostomial regions of the carapace sidewall, and one inferior margin of the merus of pereiopod 1 has small granules, while the other margin is smooth. The major dactylus of the cheliped of this specimen is strongly arched and the dentition on the propodus has a large proximal molariform cluster. All of these characters were found here to vary with age (see below), and it is clear that $H$. madagascariensis exhibits a great deal of intraspecific variation. The moults that occur in adult males of $H$. madagascariensis (cw $50 \mathrm{~mm}$ and above) bring about a transformation of the carapace and cheliped characters that are different enough to have prompted some authors to describe different life stages of this taxon as different species. For example, Rathbun (1904) described Potamon (Potamon) humbloti Rathbun, 1904 from a subadult male specimen that was later re-identified and synonymized with $H$. madagascariensis (Cumberlidge and Sternberg, 2002).

We consider it likely, based on the present work, that A. Milne-Edwards' (1872) original description of Thelphusa madagascariensis was based on a subadult specimen, whereas Rathbun's (1904) description of Potamon (Potamon) bombetokensis from an adult male specimen (cw $50.1 \mathrm{~mm}$ ), and Cumberlidge and Sternberg's (2002) description of $H$. bombetokensis from even larger specimens (cws 50-61 mm), were each using adult specimens of $H$. madagascariensis.

The large series of specimens of $H$. madagascariensis available for the present study made it possible to describe intraspecific variation shown by characters of the carapace and chelipeds that have previously been considered to be diagnostic for the species. Examination of a series of specimens of different sizes (ages) that included juveniles (cw $<30 \mathrm{~mm}$ ), subadults (cws 30-49 $\mathrm{mm}$ ) and adults (cws $50 \mathrm{~mm}$ or greater) from the same geographical locality (FMNH 5464 and 5471) revealed the following variation in characters: (1) the anterolateral regions of the dorsal carapace of adults are smooth and arched, whereas these regions in juveniles and subadults are 
granulated and flattened; (2) the suborbital and pterygostomial regions of the carapace sidewall of adults are distinctly granulated, whereas these regions in juveniles and subadults are either smooth, or only faintly granulated; (3) the inferior margins of the merus of pereiopod 1 of adults are distinctly granulated, whereas these margins in juveniles and subadults are either only weakly granulated, or completely smooth; and (4) the cheliped of adult males has undergone a dramatic transformation: the dactylus is distinctly curved to form an arch that encloses a permanent gape, and the propodus has developed a characteristic large proximal molariform cluster with three or four fused teeth. The cheliped of subadult males $(30-49 \mathrm{~mm})$ and juveniles ( $\mathrm{cw}<29 \mathrm{~mm}$ ) lacks the curved dactylus and the proximal molariform cluster on the propodus is unformed and inconspicuous.

Specimens of similar size from different geographical localities in the north-east (FMNH 6637), central (FMNH 5772) and south-east (FMNH 5762) parts of the island did show variation in the colour of their carapace and legs, but did not show a great deal of variation in carapace or gonopod characters. Specimens of $H$. madagascariensis from Marojejy in Antsiranana Province (FMNH 6633, 6636) and from Ilefitany in the Réserve Spéciale du Pic d'Ivohibe in Fianarantsoa Province (FMNH 5464) have a distinct covering of short peach fur on their dorsal carapace. The subadult female (FMNH 5749) from the river Manampatrana in Fianarantsoa Province has several character states (carapace outline and pointed exorbital and epibranchial teeth) that are similar to those of $H$. agilis. However, characters of the suborbital margin, carapace sidewalls, and merus and carpus of pereiopod 1 of this specimen indicate that it belongs to $H$. madagascariensis.

Comparisons. Hydrothelphusa madagascariensis can be distinguished from $H$. agilis and $\mathrm{H}$. goudoti as follows. The frontal margin of the carapace of $\mathrm{H}$. madagascariensis is neither horizontal (as in $\mathrm{H}$. agilis) nor strongly deflexed (as in $\mathrm{H}$. goudoti); in addition, the suborbital margin of $H$. madagascariensis is granulated but it is neither strongly toothed (as in $\mathrm{H}$. agilis) nor smooth (as in $\mathrm{H}$. goudoti); the subhepatic and pterygostomial regions of the carapace sidewall of $H$. madagascariensis are granulated but not smooth (as in $H$. agilis and $H$. goudoti), and the fingers of the right and left propodi of the chelipeds of adult males of $H$. madagascariensis has a characteristic large molariform cluster of three or four fused teeth which are not seen in $H$. agilis and $H$. goudoti.

Hydrothelphusa madagascariensis can be further distinguished from $H$. goudoti by the following characters. The carapace of $H$. madagascariensis is less wide (cw/fw 3.4) and less arched (ch/fw 1.3) than that of $H$. goudoti (cw/fw 3.9, ch/fw 1.6); the exorbital angle tooth and the epibranchial tooth of $H$. madagascariensis are both large and triangular, whereas these teeth in $H$. goudoti are small and blunt; the suborbital and pterygostomial regions of the carapace sidewall of $H$. madagascariensis are both heavily granulated, whereas those of $H$. goudoti are smooth; and the cervical grooves of $H$. madagascariensis are very short, whereas those of $H$. goudoti are very long.

Differences in the carapace proportions between $H$. madagascariensis and $H$. bombetokensis (carapace width, cw/fw 3.4 versus 3.5, and carapace height, ch/fw 1.2 versus 1.3) reported by Cumberlidge and Sternberg (2002) are probably not significant in the light of the findings of the present study. Similarly, differences in carapace texture (either granular with carinae, or smooth) used to distinguish between $H$. madagascariensis and $H$. bombetokensis are also not supported in the present study, 
and could be accounted for by intraspecific variability in these characters. Finally, no significant differences could be found between the form of the terminal article of gonopod 1 in $H$. madagascariensis and in specimens formerly assigned to H. bombetokensis. This knowledge of character variability has been derived from the examination of a large series of specimens of different ages, and makes the boundaries between $H$. madagascariensis and $H$. bombetokensis very unclear. For these reasons we do not recognize $H$. bombetokensis here as a distinct taxon.

Hydrothelphusa goudoti (H. Milne Edwards, 1853)

(figure 2C)

Thelphusa goudoti H. Milne Edwards, 1853: 212. A. Milne-Edwards, 1869: 172, pl. 8, figure 4a, b; 1887: 135 (type locality: road between Bombetok and Antananarivo, Madagascar).

Telphusa goudoti de Man, 1892: 235.

Potamon goudoti de Man, 1898: 434.

Potamon (Potamon) goudoti Rathbun, 1904: 305-306, figure 34, pl. 13, figure 10; Balss, 1929: 355.

Potamon (Geothelphusa) methueni Calman, 1913: 920 (type locality: Imerimandrosa, Madagascar).

Bottia goudoti Pretzmann, 1961: 164, figure 3.

Gecarcinautes goudoti Bott, 1965: 338-339, pl. 2 figures 6, 7; Cumberlidge, 1997: 585; 1998: 209.

Hydrothelphusa goudoti Cumberlidge and Sternberg, 2002: 56-59, figures 1D, 3D, 4D, 5D, $6 \mathrm{D}, 7 \mathrm{G}, \mathrm{H}, 8 \mathrm{D}, 9 \mathrm{~J}-\mathrm{M}, 11 \mathrm{D}$, tables 1-4.

Material examined. Madagascar: four males (cws 45.8, 37.1, 36.4, $34.7 \mathrm{~mm}$ ) collected with $H$. madagascariensis (FMNH 5720).

Type locality. Madagascar. Thelphusa goudoti: road between Bombetok and Antananarivo. Potamon (Geothelphusa) methueni: Imerimandrosa, near Lake Alaotra, Toamasina Province $\left(17^{\circ} 30^{\prime} \mathrm{S}, 48^{\circ} 30^{\prime} \mathrm{E}\right)$.

Distribution. Hydrothelphusa goudoti is found in streams, rivers and lakes in the north-western, central and south-eastern regions of Madagascar in Antsiranana, Antananarivo and Toamasina provinces (figure 2C). Figure 2C shows six different localities for H. goudoti, from the literature (Cumberlidge, 1997, 1998; Cumberlidge and Sternberg, 2002). Hydrothelphusa goudoti is found in five major river basins in three provinces between $13^{\circ}$ and $24^{\circ} \mathrm{S}$, from the Tsaratanana massifin the north, to the Marotsy River near Androkabe in the south-east. Hydrothelphusa goudoti is not known from either the north-western Province of Mahajanga or the western and southern Province of Toliara (except for the extreme south-east of this province), and there are no records from Fianarantsoa Province.

Remarks. Hydrothelphusa goudoti was described in 1853, the first freshwater crab described from Madagascar. Hydrothelphusa goudoti is characterized by its prominent post-frontal crest, smooth carapace texture, small epibranchial and exorbital teeth, and unusual carapace proportions: it has the widest, longest and most arched carapace of any species in this genus. The distinguishing differences between $H$. goudoti, $H$. agilis and $H$. madagascariensis are provided above.

Conservation status. Although $H$. goudoti is locally common in the central highlands of Madagascar and is offered for sale in the market in Antananarivo, it is still known from only a few localities, and its status is threatened (table 1). 


\section{Madagapotamon humberti Bott, 1965}

(figure 2D)

Madagapotamon humberti Bott, 1965: 344-346, figure 7, pl. 4, figures 14-17; Vuillemin, 1970: 245-265; Ng and Takeda, 1994: 162-163, table 1; Cumberlidge and Sternberg, 2002: 65, 67-68, figures 2E, 3G, 4L, 5H, 6G, 7K, L, 8G, 10G, H, 11H, tables 1-4.

Material examined. All coll. S. M. Goodman. Madagascar: one adult female (cw $41.4 \mathrm{~mm}$ ), one subadult male (cw $26.9 \mathrm{~mm}$ ), one juvenile female $(\mathrm{cw} 18.6 \mathrm{~mm})$, forest near the Andrafiabe cave, Réserve Spéciale d'Ankarana (FMNH 6706); one adult female, forest near the Andrafiabe cave, Réserve Spéciale d'Ankarana (FMNH 6707); one subadult male (cw $34.5 \mathrm{~mm}$ ), one subadult female (cw $32.4 \mathrm{~mm}$ ), forest near the Andrafiabe cave, Réserve Spéciale d'Ankarana (FMNH 6708).

Type locality. Northern Madagascar, between 'Ankara and Analamera'. The locality 'Ankara' is almost certainly Ankarana (Vuillemin, 1970).

Distribution. Northern Madagascar, Ankarana, Montagne des Français and Nosy Be. Madagapotamon humberti is found in the Ankarana massif (Antsiranana Province) about $100 \mathrm{~km}$ south-west of Antsiranana, to the north of Ambilobe (figures 2D, 5). Figure 2D includes localities for $M$. humberti from the literature (Cumberlidge and Sternberg, 2002). The Ankarana massif is an undeveloped region of limestone formations (karst) consisting of caves and underground rivers with numerous forested valleys forming the Réserve Spéciale d'Ankarana. Ankarana is aligned obliquely north-east/south-west and forms the western part of a limestone plateau lying to the south of the Parc National de la Montagne d'Ambre. This limestone plateau continues eastward as the Andrafiamena-Analamera escarpment, which ends close to the Baie du Loky. The Ankarana and Andrafiamena escarpments are separated by a low-lying region occupied by the main road between Ambilobe and Antsiranana (Vuillemin, 1970). Madagapotamon humberti is also found on the slopes of the Anosiravo mountains (Antsiranana Province) and Montagne des Français (Vuillemin, 1972) a few kilometres south of Antsiranana. Photographs of the specimens in Vuillemin (1972) are strikingly like Madagapotamon, rather than Malagasya. Cumberlidge and Sternberg (2002) also reported that M. humberti occurs on the nearby island of Nosy Be (Antsiranana Province).

Remarks. Madagapotamon is closest to Malagasya, which shares the heart-shaped carapace outline, distinct teeth on the anterolateral margins and slender elongated walking legs (Cumberlidge and Sternberg, 2002). The two genera can be easily distinguished by differences in the mandible (Madagapotamon has a simple terminal segment, Malagasya has a bilobed terminal segment) and third maxilliped (Madagapotamon lacks a flagellum on the exopod, Malagasya has a long flagellum). In life, Madagapotamon has a light brown carapace and extremely long, strikingly purple-coloured walking legs.

Conservation status. Madagapotamon humberti is restricted to a specialized habitat (limestone karst) and it is known from less than 20 specimens, some of which were collected recently and are reported herein. Its conservation status is extremely rare/ highly endangered (table 1). This species is found in a protected area, the Réserve Spéciale d'Ankarana (Antsiranana Province).

Marojejy longimerus Cumberlidge, Boyko and Harvey, 2002 (figures 3A, 5)

Marojejy longimerus Cumberlidge, Boyko and Harvey, 2002: 67-71, figures 1-3; Cumberlidge and Sternberg, 2002: 71, 73, figures $2 \mathrm{~F}, 3 \mathrm{H}, 4 \mathrm{G}, 5 \mathrm{G}, 6 \mathrm{H}, 7 \mathrm{O}, \mathrm{P}, 8 \mathrm{~F}, 10 \mathrm{I}, \mathrm{J}, 11 \mathrm{E}$, tables 1 , 3,4 . 


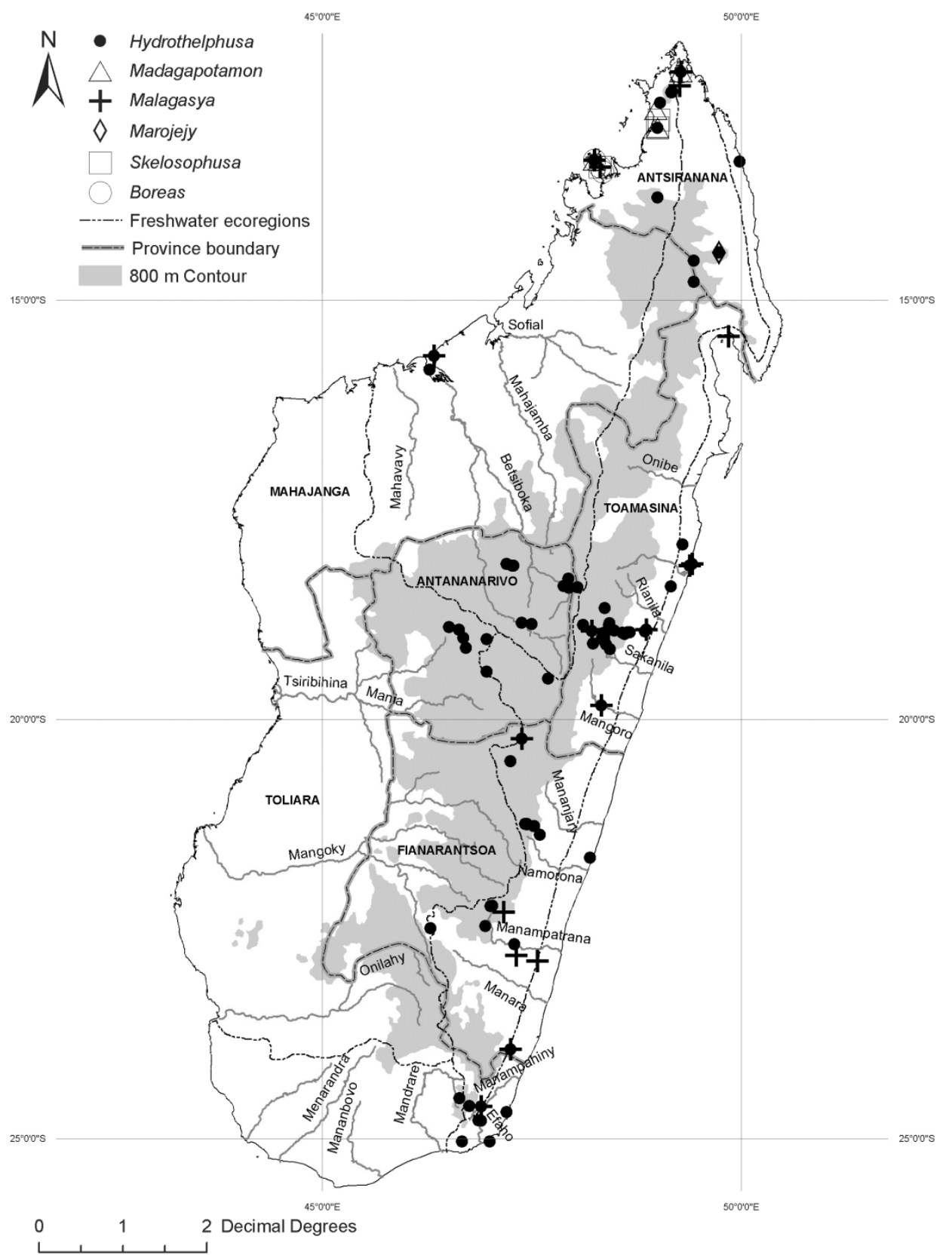

FIG. 4. Summaries of the known distributions of the six genera of Malagasy freshwater crabs. Hydrothelphusa (black circle); Malagasya (cross); Madagapotamon (triangle); Skelosophusa (square); Marojejy (diamond); Boreas (circle). Data for Malagasya and Skelosophusa are taken from Cumberlidge and Sternberg (2002). Black broken lines indicate freshwater ecoregion boundaries, shaded broken lines indicate provincial boundaries, and the shaded area indicates land at, and above, the $800 \mathrm{~m}$ contour. 


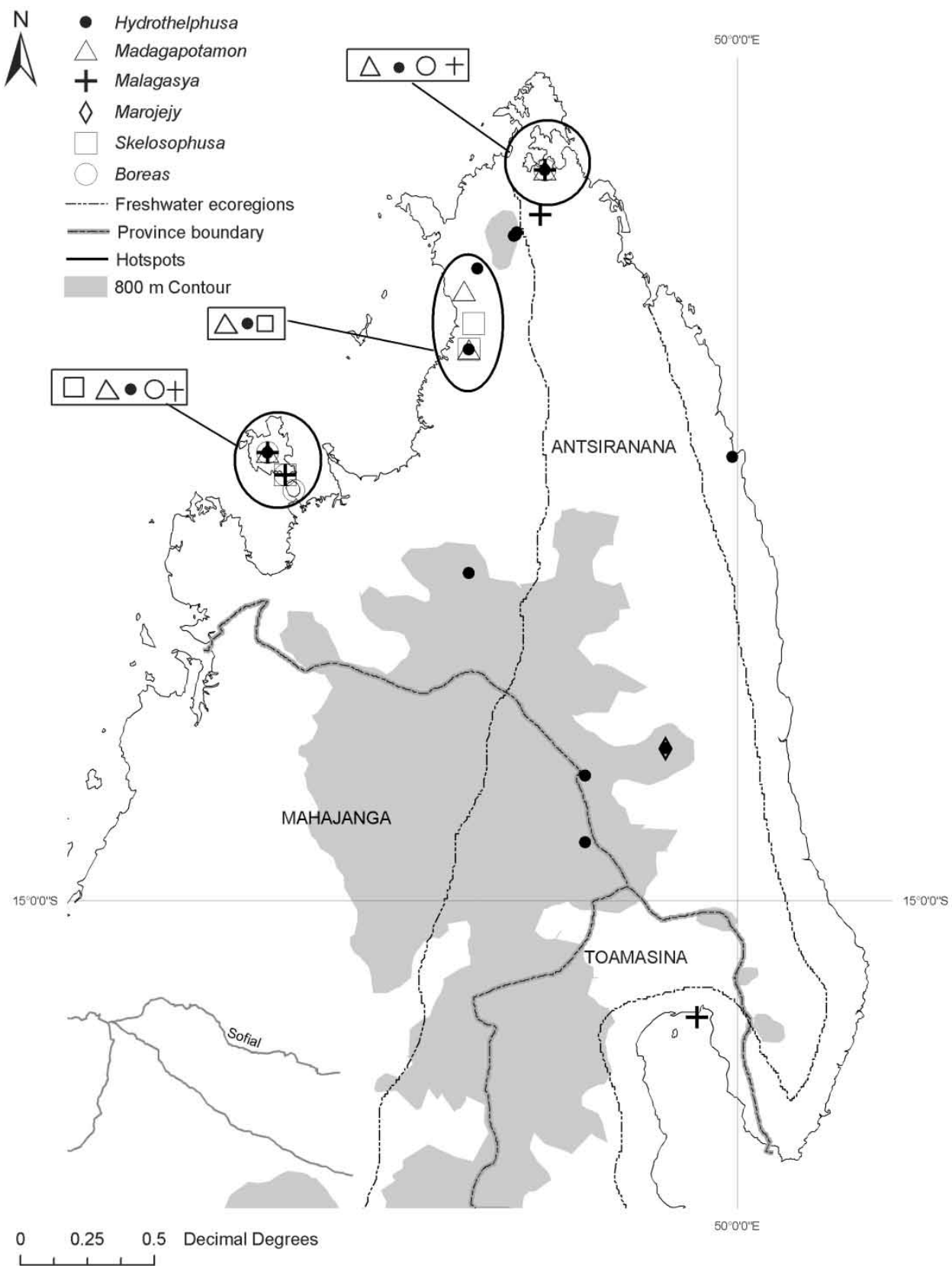

FIG. 5. Detail of the distributions of the genera of Malagasy freshwater crabs found in Antsiranana Province in northern Madagascar. Hydrothelphusa (black circle); Malagasya (cross); Madagapotamon (triangle); Skelosophusa (square); Marojejy (diamond); Boreas (circle). Data for Malagasya and Skelosophusa are taken from Cumberlidge and Sternberg (2002). The type locality of Skelosophusa eumeces is listed as 'Andrafiabe' by Ng and Takeda (1994), which was interpreted by Cumberlidge and Sternberg (2002) as 'Andrafi(a)be', $17^{\circ} 27 \mathrm{~S}, 44^{\circ} 44 \mathrm{E}^{\prime}$ in Mahajanga Province. We consider it more likely that this locality is 'Andrafiabe', a cave system in the Réserve Spéciale d'Ankarana in Antsiranana Province. Black broken lines indicate freshwater ecoregion boundaries, shaded broken lines indicate provincial boundaries, and the shaded area indicates land at, and above, the $800 \mathrm{~m}$ contour. 
Material examined. Madagascar; one male (cw $21.6 \mathrm{~mm}$ ), Marojejy, camp IV, $1600 \mathrm{~m}$ asl, $14^{\circ} 26^{\prime} \mathrm{S}, 4^{\circ} 44^{\prime} \mathrm{E}$ (FMNH 6640). Two males (cws 18.5, $23.2 \mathrm{~mm}$ ), one female (cw $20 \mathrm{~mm}$ ), Marojejy, camps IV and V, 1600-1900 $\mathrm{m}$ asl, $14^{\circ} 26^{\prime} \mathrm{S}, 49^{\circ} 44^{\prime} \mathrm{E}$ (FMNH 6635).

Type locality. Andranomifototra River (14 26 $\left.6^{\prime} 8^{\prime \prime} \mathrm{S}, 49^{\circ} 44^{\prime} 1^{\prime \prime} \mathrm{E}\right) 1875 \mathrm{~m}, 11 \mathrm{~km}$ north-west of Manantenina, Province d'Antsiranana, Réserve Naturelle Intégrale (now Parc National) de Marojejy, Madagascar.

Distribution. This monotypic genus is known only from the Parc National de Marojejy in Antsiranana Province, in the northern highlands of Madagascar (figures 3A, 5). The northern highlands are geographically separated from the classically defined central highlands by a low-lying area in the Madritsara divide that topographically isolates these two zones (Carleton and Goodman, 1998). M. longimerus has so far been collected only at high altitudes, and the specimens reported here, as well as the type specimens (AMNH 17833, FMNH 4656), were all collected between 1600 and $1900 \mathrm{~m}$ asl. Hydrothelphusa madagascariensis is also found in the Parc National de Marojejy, but at slightly lower elevations, between 800 and $1200 \mathrm{~m}$ asl.

Conservation status. Marojejy longimerus is restricted to high-altitude forest, it is known only from a few specimens, and was only discovered in the last 2 years. Its conservation status is extremely rare/highly endangered (table 1). This species is found in a protected area, the Parc National de Marojejy (Antsiranana Province).

Boreas uglowi Cumberlidge and Sternberg, 2002 (figures 3B, 5)

Madagapotamon ankaraharae Bott, 1965 (part): 347-348, figure 9d, e, pl. 5, figures 23-25 (not figure $9 \mathrm{a}-\mathrm{c}$ ).

Boreas uglowi Cumberlidge and Sternberg, 2002: 75-77, figures 2D, 3G, 4L, 5H, 6L, 7Q, R, $8 \mathrm{E}, 10 \mathrm{~A}, \mathrm{~B}, 11 \mathrm{~L}$, tables $1-4$.

Material examined. Madagascar: one male (FMNH 5732). One subadult female (cw $27.1 \mathrm{~mm}$ ) (FMNH 6709).

Type locality. Nosy Be, Madagascar.

Distribution. Boreas uglowi is known only from three localities: Nosy Be, Nosy Komba and near Antsiranana city (Cumberlidge and Sternberg, 2002), all in the extreme north of Madagascar in Antsiranana Province (figures 3B, 5).

Conservation status. Boreas uglowi is restricted to the extreme north-western part of the island. It is known only from a few specimens, and little is known of its ecology. The specimens reported on here represent the first new material to be collected for more than 80 years. Its conservation status is extremely rare/highly endangered (table 1). If this is a forest-dwelling species, then the locality on Nosy Be may be from the Réserve Naturelle Intégrale de Lokobe, which would afford some protection to this species.

Remarks. It has been brought to our attention that the genus name Boreas is preocuppied by Boreas Morris, 1980, a genus of hippothoid bryozoan. A request to change the genus name of Boreas Cumberlidge and Sternberg, 2002, which is a junior homonym, to Boreasamon Cumberlidge and Sternberg, 2002 is in preparation.

\section{Distribution}

Figures 2-5 summarize the distribution patterns of the six genera and 11 species of freshwater crabs in Madagascar based on distribution data for all species taken 
from the present study and from the recent literature (Rabeharisoa, 1996; Cumberlidge, 1997, 1998; Cumberlidge and Boyko, 2001; Cumberlidge and Sternberg, 2002). Four out of the 11 species of freshwater crabs found in Madagascar (three species of Hydrothelphusa plus Malagasya antongilensis) have a broad distribution in three or more provinces, while the other seven species (Skelosophusa gollardi, S. prolixa and S. eumeces, Boreas uglowi, Madagapotamon humberti, Marojejy longimerus, and Malagasya goodmani) are limited to a particular region of a single province.

Malagasy biomes. Three major biomes are represented in Madagascar. These are: (1) the rainforest biome in the central and northern highlands (sensu Carleton and Goodman, 1998) from Marojejy in the north to the Anosyennes Mountains in the south-east. This biome is characterized by mid-altitude humid evergreen forest above $800 \mathrm{~m}$, and low altitude humid broadleaf forest below $800 \mathrm{~m}$; (2) the seasonally dry deciduous forest and dry savanna biome in the western lowland river basins; and (3) the extremely arid south-western and southern xeric biome dominated by xerophytic plant communities. Freshwater crabs are most common in the rainforest biome, rare in the dry deciduous forest and savanna biome, and absent from the southern xeric biome.

Malagasy ecoregions. Five major subdivisions of Malagasy freshwaters, termed ecoregions, are recognized. These are broad areas that share a similar combination of climate, vegetation, geology, altitude and biological communities (Skelton, 1993). In South Africa (Skelton, 1993) and in Madagascar (Sparks and Stiassny, in press; Thieme et al., in press), ecoregions have been recognized based primarily on the distribution patterns of freshwater fishes where the distributions of endemic species overlap. The Malagasy ecoregions are indicated on figures 1-5 and table 1. These are: (1) the north-western river basins, (2) the western river basins, (3) the eastern highlands (central and northern highlands) above $800 \mathrm{~m}$, (4) the eastern lowlands below $800 \mathrm{~m}$, and (5) the southern river basins.

(1) North-western river basins. Elouard and colleagues surveyed about a dozen different freshwater localities below $800 \mathrm{~m}$ asl in the north-western river drainage ecoregion (mostly in the Betsiboka river basin), and found no freshwater crabs to be present (figure 1). Elouard et al., also surveyed more than 50 sites above $800 \mathrm{~m}$ asl in this ecoregion, and found no freshwater crabs in Mahajanga Province, but did demonstrate the presence of $H$. agilis and $H$. madagascariensis in the headwaters of the Betsiboka River in Antanarivo Province (figure 2A, B). Elsewhere in the north-western river basins ecoregion, sampling by Elouard et al., was light, and mainly in the vicinity of Antsiranana ( $H$. agilis and $H$. madagascariensis present) and Marojejy (H. madagascariensis present). The majority of the freshwater crab records for Antsiranana Province reported on in the present study (figures 2-5) come from either the collections of S. M. Goodman, or from museum specimens (see Cumberlidge and Sternberg, 2002).

Five out of six genera of freshwater crabs from Madagascar occur in the northwestern coastal lowlands (figures 2-5), including two monotypic genera (Boreas and Madagapotamon), one species of Malagasya, three species of Skelosophusa, and two species of Hydrothelphusa (Cumberlidge and Sternberg, 2002). Five of these species (Madagapotamon humberti, B. uglowi, S. gollardi, S. prolixa and S. eumeces) have a narrow distribution in the north-western coastal lowlands between Ambanja, Ambilobe and Antsiranana (figures 2D, 3B, 3D, 4, 5), and on the nearby islands, while three species (Malagasya antongilensis, $H$. agilis and $H$. madagascariensis) also 
occur in the central and southern parts of the island (figures 2A, B, 3C). One endemic monotypic genus (Marojejy) is restricted to the high altitude forest in the highland region of south-east Antsiranana Province (figures 3A, 4, 5).

The highest diversity of freshwater fishes is found in the north-western basins of Madagascar, where 70 species occur, of which 29 are endemic to the ecoregion (Sparks and Stiassny, in press). On a smaller scale, this finding is also the case for freshwater crabs in the north-western basins where species diversity is highest, with eight species, of which five are endemic to the ecoregion. It is likely that these estimates of freshwater crab biodiversity in north-western Madagascar, like those for freshwater fish (Sparks and Stiassny, in press), are an underestimate. This is because the absence of records for freshwater crabs in the southern part of the north-western river basin ecoregion below $800 \mathrm{~m}$ asl may be related to the fact that the rivers draining the Tsaratanana massif, as well as a number of other drainages in north-western Madagascar, remain largely unsurveyed (figure 1).

On the basis of current information and levels of island-wide exploration, we recognize three localized areas that are characterized by the overlapping distributions of at least two endemic taxa, each with a narrow range. The areas where these overlaps occur represent centres of endemism (biodiversity hotspots) for freshwater crabs in Madagascar. The centres of endemism are all in the north-western river basin ecoregion, in northernmost coastal lowlands in Antsiranana Province between Nosy Be and Antsiranana (figure 5). The three centres are: (1) Nosy Be and Nosy Komba (for Madagapotamon, Boreas and Skelosophusa), (2) Ankarana (for Madagapotamon and Skelosophusa), and (3) Montagne des Francais, near Antsiranana (for Madagapotamon and Skelosophusa). Two of the freshwater crab centres of endemism lie in the north-western river basin ecoregion, while the other one (Montagne des Français, near Antsiranana) is part of the northern tip of the eastern highlands ecoregion (figure 5). These three centres of endemism for freshwater crabs are not biodiversity hotspots for freshwater fishes (Sparks and Stiassny, in press).

$(2,3)$ Eastern highland and eastern lowland river basins. Elouard and colleagues surveyed more than 100 different freshwater localities above $800 \mathrm{~m}$ asl in the eastern highland river basins and over 85 localities below $800 \mathrm{~m}$ asl in the eastern lowland ecoregion (figure 1). Together with material from the collection efforts of S. M. Goodman and specimens in museum collections, this makes the freshwater habitats of the central and northern highlands and the forested eastern coastal lowlands the most surveyed parts of the island for freshwater crabs (figure 1). Freshwater crab distribution broadly conforms to the limits of the eastern (central and northern) highland and eastern lowland ecoregions from sea level to $1800 \mathrm{~m}$, but there is no obvious subdivision into a highland and lowland fauna that is seen in the distribution patterns of freshwater fishes (Sparks and Stiassny, in press). About 50 species of freshwater fishes are present in the eastern highlands and 22 of these are endemic to the ecoregion, whereas species diversity is higher in the eastern lowlands, with 69 species, of which 16 are endemic (Sparks and Stiassny, in press). The data presented here for freshwater crabs indicate that there is little difference in diversity between the eastern highland and eastern lowland ecoregions. Both are moderately speciose, with one out of five species endemic to the ecoregion in each case. The southern limit of the distribution of freshwater crabs in the eastern highland and eastern lowland ecoregions (figures 2-5) corresponds to the boundary between the yearround freshwater habitats of the humid forest zone and the seasonally dry waterways 
of the arid south-west. All three species of Hydrothelphusa are found in the eastern highland and eastern lowland ecoregions (figure $2 \mathrm{~A}-\mathrm{C}$ ), as is Malagasya antongilensis which occurs in the forested highlands and lowlands of Toamasina and Fianarantsoa Provinces (as well as in the north-western lowland coast of Antsiranana and Mahajanga Provinces) (figure 3C). This species is not known from Antananarivo Province, and is absent from Toliara Province except for the forested highlands in the south-east of the province. Malagasya goodmani has a very restricted distribution and is known only from the type locality in the eastern lowland forests of the northern part of Toamasina Province (figure 3C).

(4) Western river basins. Surveys by Elouard and colleagues of the freshwater habitats of the large area of lowland dry deciduous forest and savanna that comprises the western river basins of Madagascar included more than 80 different localites (figure 1). Of these, more than 30 localities were in the lower reaches of the major rivers that drain this region - such as the Onilahy, Mangoky, Tsiribihina, Mahavavy, Mahajamba and Sofia - below $800 \mathrm{~m}$ asl, and resulted in no records of freshwater crabs. In contrast, three species of Hydrothelphusa were found in several of the more than 50 different localities sampled above $800 \mathrm{~m}$ asl on the headwaters of the major rivers that originate on the western slopes of the western river basins ecoregion in south-western Antananarivo Province (figure 2A-C). The western limit of the distribution of freshwater crabs (figure 1) corresponds to the limits of the headwaters of the rivers draining the central highlands, and the beginning of the slower-flowing, more turbid, seasonally dry rivers flowing through the deciduous forests and dry savannas of western Madagascar.

The absence of freshwater crabs from the lower reaches of the major rivers in the western drainages may be accounted for by the drier climate with lower rainfall, and by the tidal nature of the lower reaches of some of the rivers. During the dry season (from April until November) many of these freshwater habitats are subjected to lower water levels and warmer water temperatures, and some may experience complete desiccation. The tidal influence in the lower and middle reaches of these western rivers (Kiener and Richard-Vindard, 1972) may also influence the presence of freshwater crabs. This is because freshwater crabs exhibit a strong aversion to saltwater and are not known to occur either in full-strength seawater or even brackish water environments, in any part of their range globally (Cumberlidge, 1999). Some 49 species of freshwater fishes are present in the western river basins, but only seven are endemic to the ecoregion (Sparks and Stiassny, in press).

(5) Southern river basins. Elouard and colleagues surveyed more than 25 different freshwater localities below $800 \mathrm{~m}$ asl in the southern river basins (figure 1), but this effort produced no records of freshwater crabs, even in the major rivers that flow through this region (such as the Menarandra, Mananbovo and Mandrare). It would appear that freshwater crabs are completely absent from this south-western xeric region south of a line between Toliara (Tuléar) and Tolagnaro (Fort Dauphin) (figure 1). Many of the rivers in the extreme south-west dry up completely during the dry season, and others retain only low levels of relatively warm water. These conditions would make it difficult for most species of freshwater crabs to survive. However, their presence cannot be wholly discounted, because some species of freshwater crabs from the dry West African savanna in northern Nigeria have adapted to live year-round in similarly seasonally arid conditions (Cumberlidge, 1986, 1999). Freshwater fishes are found in the southern river basins, but their diversity is very low, with only 10 species present, of which two are endemic to the ecoregion (Sparks and Stiassny, in press). 
Regional diversity of freshwater crabs. The only other locality in the Mascarene region, besides Madagascar, where true freshwater crabs are found is the granitic Seychelles Islands (Praslin, La Digue and Mahé), where the endemic monotypic genus Seychellum alluaudi (A. Milne-Edwards and Bouvier, 1893) occurs ( $\mathrm{Ng}$ et al., 1995). Freshwater crabs are not found in the coralline Seychelles Islands, Comoro Islands, Réunion, Mauritius and Rodrigues. Endemism for freshwater crabs in Madagascar is $100 \%$ at the species and genus level. The family, however, is not endemic, with all Malagasy freshwater crabs currently assigned to one African family, the Potamonautidae Bott, 1970 (Cumberlidge and Sternberg, 2002). The freshwater crabs of Madagascar are a relatively neglected group with a complicated taxonomic history, and we are only now beginning to understand their true diversity. The Malagasy freshwater crab fauna has been reviewed only twice: by Bott (1965), who recognized seven species in three genera, and by Cumberlidge and Sternberg (2002), who listed 12 species in six genera. This increase in the number of taxa is due in part to greater taxonomic discrimination, and in part to recent collection efforts (table 1), and underlines the importance of the need to collect in the more remote regions of the island. Compared to freshwater fishes, the freshwater crabs of Madagascar comprise a relatively impoverished but highly endemic and poorly surveyed fauna. The most recent survey of Malagasy freshwater fishes (Sparks and Stiassny, in press) indicates that 91 out of 141 species, 13 out of 54 genera and two out of 21 families of native freshwater fish are endemic.

\section{Conclusions}

The factors influencing the distribution of freshwater crabs in Malagasy freshwaters are broadly the same as those limiting the distribution of freshwater fishes to a particular ecoregion, but there are areas of disagreement between the distribution patterns shown by these two groups. First, both freshwater fishes and freshwater crabs are most abundant in the forested areas in the northern and eastern part of the island that support permanent water sources and receive year-round rainfall. However, freshwater crabs (unlike freshwater fishes) are not most diverse in the eastern highland ecoregion. Second, freshwater crabs are equally abundant in freshwater habitats from sea level to the highland areas, and altitude does not appear to influence the distribution of freshwater crabs, as it does for freshwater fishes. Finally, the combination of climatic and hydrological conditions (especially temperature and saline incursions) may account, at least in part, for the absence of freshwater crabs (and for the reduced diversity of freshwater fishes) in the western and southern river basin ecoregions. The impact of introduced species on populations of freshwater fishes in Madagascar has been considerable (Sparks and Stiassny, in press), but the impact of exotic species on freshwater crabs has yet to be evaluated.

Although great advances have been made in our knowledge of Malagasy freshwater habitats in general, at the present state of our knowledge of the distribution of freshwater crabs in Madagascar it is difficult to draw firm conclusions about the meaning of the absence of records for large parts of the island that have not yet been surveyed, especially the more inaccessible regions away from population centres and roads.

\section{Acknowledgements}

We are grateful to Dr Steven M. Goodman (FMNH) for giving us the opportunity to examine these specimens. We also thank Dr Goodman and 
Dr Melanie L. J. Stiassny (AMNH) for their helpful comments and insights on the interpretation of the distributional data. Dr Jean-Marc Elouard and his colleagues of the Institut de Recherche pour le Développement (IRD, ex. ORSTOM), Madagascar, are thanked for kindly sharing their extensive collection data. Also contributing to the collection effort were: François-Marie Gibon (IRD), Mahefason Andriamihaja and Abel Ralateferana (Centre national de Recherche sur l'Environnement malgache), Landi Andriamanantena, Rizaivony Andriamasimanana, Zoé Patricia Andriambelo, Laurence Blanc, Erika Doumenq, Ranalison Oliarinony, Théogène Pilaka, Zoelisoa Sophie Rabeantandro, Fabienne Ranaivoharindriaka, Henry Ranarijaona, Désiré Randriamasimanana and Bako Rabearisoa (Université d'Antananarivo), Jean Legrand (Muséum national d'Histoire naturelle de Paris), Jean-Luc Gattolliat, Laurence Ruffieux and Michel Sartori (Musée zoologique Cantonal de Lausanne), and T. Nguyen and Eric Quenter (AMNH).

\section{References}

BALSS, H., 1929, Über Ostafrikanischer Potamonidae (Decapoda), Mit Anhang: Potamoiden von Madagaskar, Zoologische Jahrbücher, Abteilung für Systematik, 58, 339-358.

Botт, R., 1965, Die Süßwasserkrabben von Madagaskar, Bulletin du Muséum national d'Histoire naturelle (Paris), 37(2), 335-350.

Bотт, R., 1970, Die Susswasserkrabben von Europa, Asien, Australien und ihre Stammesgeschichte, Abhandlungen der Senckenbergischen Naturforschenden. Gesellschaft Deutsch, 526, 1-338.

Calman, W. T., 1913, On freshwater decapod Crustacea (Families Potamonidae, Palaemonidae) collected in Madagascar by the Hon. Paul A. Methuen, Proceedings of the Zoological Society of London, 914-932.

Carleton, M. D. and Goodman, S. M., 1998, New taxa of nesomyine rodents (Muroidea: Muridae) from Madagascar's northern highlands, with taxonomic comments on previously described forms, in S. M. Goodman (ed.) A Floral and Faunal Inventory of the Réserve Spéciale d'Anjanaharibe-Sud, Madagascar: With Reference to Elevational Variation, Fieldiana: Zoology, new series, 90, 163-200.

Cumberlidge, N., 1986, Ventilation of the branchial chambers in the amphibious West African fresh-water crab Sudanonautes (Convexonautes) aubryi monodi (Balss, 1929) (Brachyura, Potamonautidae), Hydrobiologia, 134, 53-65.

Cumberlidge, N., 1997, The African and Malagasy freshwater crabs in the Museum of Natural History, Vienna (Crustacea: Decapoda: Brachyura: Potamoidea), Annalen des Naturhistorischen Museums in Wien, 1999B, 571-589.

Cumberlidge, N., 1998, The African and Malagasy freshwater crabs in the Zoologische Staatssammlung, Munich (Crustacea: Decapoda: Brachyura: Potamoidea), Spixiana, 21(3), 193-214.

Cumberlidge, N., 1999, The freshwater crabs of West Africa, family Potamonautidae, in Faune et Flore Tropicales, Vol. 35 (Paris: Institut de Recherche pour le Développement (IRD, ex-ORSTOM)), pp. 1-382.

Cumberlidge, N. and Boyko, C. B., 2001, Chapitre 6, Les crabes d'eau douce et les écrevisses (Crustacea: Decapoda: Brachyura et Astacoidea) du corridor Ranomafana-Andringitra à Madagascar, in S. M. Goodman and V. R. Razafindratsita (eds) Inventaire biologique du Parc National de Ranomafana et couloir forestier qui la relie au Parc National d'Andringitra, Série Sciences Biologiques, Vol. 17 (Institut de Recherche pour le Développement (IRD, ex-ORSTOM), Antananarivo, Madagascar), pp. 125-130.

Cumberlidge, N. and Sternberg, R. v., 2002, A taxonomic revision of the freshwater crabs of Madagascar (Decapoda: Potamoidea: Potamonautidae), Zoosystema, 24(1), 41-79.

Cumberlidge, N. and Sternberg, R. V., The freshwater crabs of Madagascar, in S. M. Goodman and J. P. Benstead (eds) A Natural History of Madagascar (Chicago: University of Chicago Press) (in press). 
Cumberlidge, N., Boyko, C. B. and Harvey, A. W., 2002, A new genus and species of freshwater crab (Decapoda, Crustacea, Potamoidea) from northern Madagascar, and a second new species associated with Pandanus leaf axils, Journal of Natural History, 36(1), 65-77.

DE Man, J. G., 1892, Decapoden des Indischen Archipels, in Max Weber, Zoologische Ergebnisse einer Reise in Niederländisch Ost-Indien, 2, 265-527, pls 15-29.

DE Man, J. G., 1898, Description d'une espèce nouvelle du Genre Potamon Sav. provenant du pays des Somalis, Annali del Museo Civico Storia Naturele di Genova, 19(2)(29), $262-270$.

Kiener, A. and Richard-Vindard, G., 1972, Fishes of the continental waters of Madagascar, in R. Battistini and G. Richard-Vindard (eds) Biogeography and Ecology in Madagascar (The Hague: W. Junk), pp. 477-499.

Milne-Edwards, A., 1869, Révision du genre Thelphusa et description de quelques espèces nouvelles faisant partie de la collection du Muséum, Nouvelles Archives du Muséum d'Histoire naturelle, Paris, 5, 161-191.

Milne-Edwards, A., 1872, Note sur les Crabes d'eau douce de Madagascar, Bibliothèque de l'École des hautes Études, Section Sciences naturelles, 5(8), 1-3.

Milne-Edwards, A., 1887, Les crabes des eaux douces de l'Afrique, Annales des Sciences naturelles, Zoologie (Paris), 7(4), 121-149.

Milne-Edwards, A. and Bouvier, E. L., 1893, Sur une espèce nouvelle du genre Deckenia (Hilgendorf), Annales des Sciences naturelles, Zoologie (Paris), 15, 325-336.

Milne Edwards, H., 1853, Observations sur les affinités zoologiques et la classification naturelle des Crustacés, Annales des Sciences Naturelles, Zoologie, (Paris), Série 3, 20, 163-128.

Morris, P. A., 1980, The bryozoan family Hippothoidae (Cheilostomata-Ascophord) with emphasis on the genus Hippothoa. Allan Hancock Monographs in Marine Biology, 10, $1-115$.

NG, P. K. L. and TAKedA, M., 1994, Skelosophusa (Crustacea, Decapoda, Brachyura), a new genus of potamonautid freshwater crab from Madagascar, with descriptions of two new species, Bulletin of the National Science Museum, (Tokyo), series A (Zoology), 20(4), 161-172.

Ng, P. K. L., Stevcic, Z. and Pretzmann, G., 1995, A revision of the family Deckeniidae Ortmann, 1897 (Crustacea: Decapoda: Brachyura: Potamoidea), with description of a new genus (Gecarcinucidae: Gecarcinucoidea) from the Seychelles, Indian Ocean, Journal of Natural History, 29, 581-600.

Pretzmann, G., 1961, Die Reptantia der Oesterreichischen Madagaskar-Expedition 1958, Memoires de l'Institut Scientifique de Madagascar, serie F, IV, 161-165.

RabeharisoA, B., 1996, Crayfish (Parastacidae) and crabs (Potamonidae) of the Réserve Naturelle Intégrale d'Andringitra, Madagascar, Fieldiana, Zoology, n.s., 85, 155-157.

Rathbun, M. J., 1904, Les crabes d'eau douce (Potamonidae), Nouvelles Archives du Muséum d'Histoire naturelle (Paris), 6(4), 255-312.

Rathbun, M. J., 1905, Les crabes d'eau douce (Potamonidae), Nouvelles Archives du Muséum d'Histoire naturelle (Paris), 7(4), 159-322.

Skelton, P. H., 1993, A Complete Guide to the Freshwater Fishes of Southern Africa (South Africa: Southern Book Publishers), pp. 1-388.

Sparks, J. S. and Stiassny, M. L. J., Introduction to the freshwater fishes, in S. M. Goodman and J. P. Benstead (eds) A Natural History of Madagascar (Chicago: University of Chicago Press) (in press).

Thieme, M. L., Abell, R. A., Olson, D. M., Dinerstein, E., Stiassny, M. L. J., Skelton, P. H. and Teugels, G. G. (eds), Freshwater Ecoregions of Africa: A Conservation Assessment (Washington, DC: World Wildlife Fund-US) (in press).

Vuillemin, S., 1970, Observations écologiques et biologiques sur Madagapotamon humberti Bott, 1965 (Crustacé, Décapode, Potamonidé) du massif de l'Ankarana (Madagascar), Annales de l'Université de Madagascar, 7, 245-266.

Vuillemin, S., 1972, Contribution à l'étude écologique de la Montagne des Français (Province de Diégo-Suarez): biologie de Gecarcinautes antongilensis antongilensis (Rathbun, 1905) (Crustacé, Décapode, Potamonidé), Annales de l'Université de Madagascar, 9, 135-166. 